Research Article

Kees Hengeveld*, Edson Rosa Francisco de Souza, Maria Luiza Braga, Valéria

Vendrame

\title{
Perception Verbs in Brazilian Portuguese: A Functional Approach
}

https://doi.org/10.1515/opli-2019-0016

Received July 10, 2017; accepted April 20, 2019

\begin{abstract}
This paper examines the semantic and morphosyntactic complementation patterns of perception verbs in Brazilian Portuguese. Using the framework of Functional Discourse Grammar, five semantic complement types are identified. It is subsequently shown that these five types are in an implicational relationship, such that the set of semantic complement types that a certain perception verb in Brazilian Portuguese may take occupies a contiguous segment on a hierarchy of semantic complement types. The morphosyntactic complements of perception verbs in Brazilian Portuguese include noun phrases, finite, and non-finite clauses, the latter comprising progressive1 and infinitival forms. The second part of the study shows that the choice for one of these types can to a high extent be predicted from the semantics of the complements, using the same hierarchy of semantic complement types.
\end{abstract}

Keywords: Perception verbs, Complement clauses, Functional Discourse Grammar, Brazilian Portuguese

\section{Introduction}

The aim of this paper is to give a systematic description of the complementation patterns exhibited, both semantically and morphosyntactically, by perception verbs in Brazilian Portuguese within the framework of Functional Discourse Grammar (FDG, Hengeveld \& Mackenzie 2008). To this end, we will first, in Section 2, give a brief outline of FDG. We then move to its treatment of perception verbs in Section 3. From this treatment a number of predictions follow, which are given in Section 4. The predictions concern the distribution of semantic complement types with perception verbs on the one hand, and the way in which the morphosyntactic complement types of perception verbs may be predicted from their semantics on the other. These predictions are tested in Sections 5 through 8. We round off the paper with our conclusions in Section 9.

1 We use the term 'progressive verb form' for the gerúndio in Brazilian Portuguese

\footnotetext{
*Corresponding author: Kees Hengeveld, Amsterdam Center for Language and Communication, University of Amsterdam, Spuistraat 134, 1012 VB Amsterdam, The Netherlands, Email: p.c.hengeveld@uva.nl

Edson Rosa Francisco de Souza, Instituto de Biociências, Letras e Ciências Exatas, Universidade Estadual Paulista, Rua Cristóvão Colombo, 2265, Jardim Nazareth, São José do Rio Preto, 15054-000 Brazil. Email: edson@ibilce.unesp.br Maria Luiza Braga, Programa de Pós Graduação em Linguística, Universidade Federal do Rio de Janeiro, Av. Horácio Macedo 2151, Cidade Universitária, Rio de Janeiro, RJ-21942-917 Brazil. Email: malubraga@terra.com.br Valéria Vendrame, independent researcher, Rua Ray Wesley Herrick, 1500, casa 138, Jardim Jóckei Club A, São Carlos-SP, 13565-090, Brazil. Email: valvendrame@yahoo.com.br
} 


\section{Functional Discourse Grammar ${ }^{2}$}

\subsection{Introduction}

Functional Discourse Grammar (Hengeveld \& Mackenzie 2008, 2010; Keizer 2015) is a theory of language structure with a strong typological basis. The overall FDG model is given in Figure 1, which shows the various levels of analysis that are recognized within the grammar: the Interpersonal ${ }^{3}$, the Representational, the Morphosyntactic, and the Phonological Levels. Each level is hierarchically ordered in layers of increasing scope.

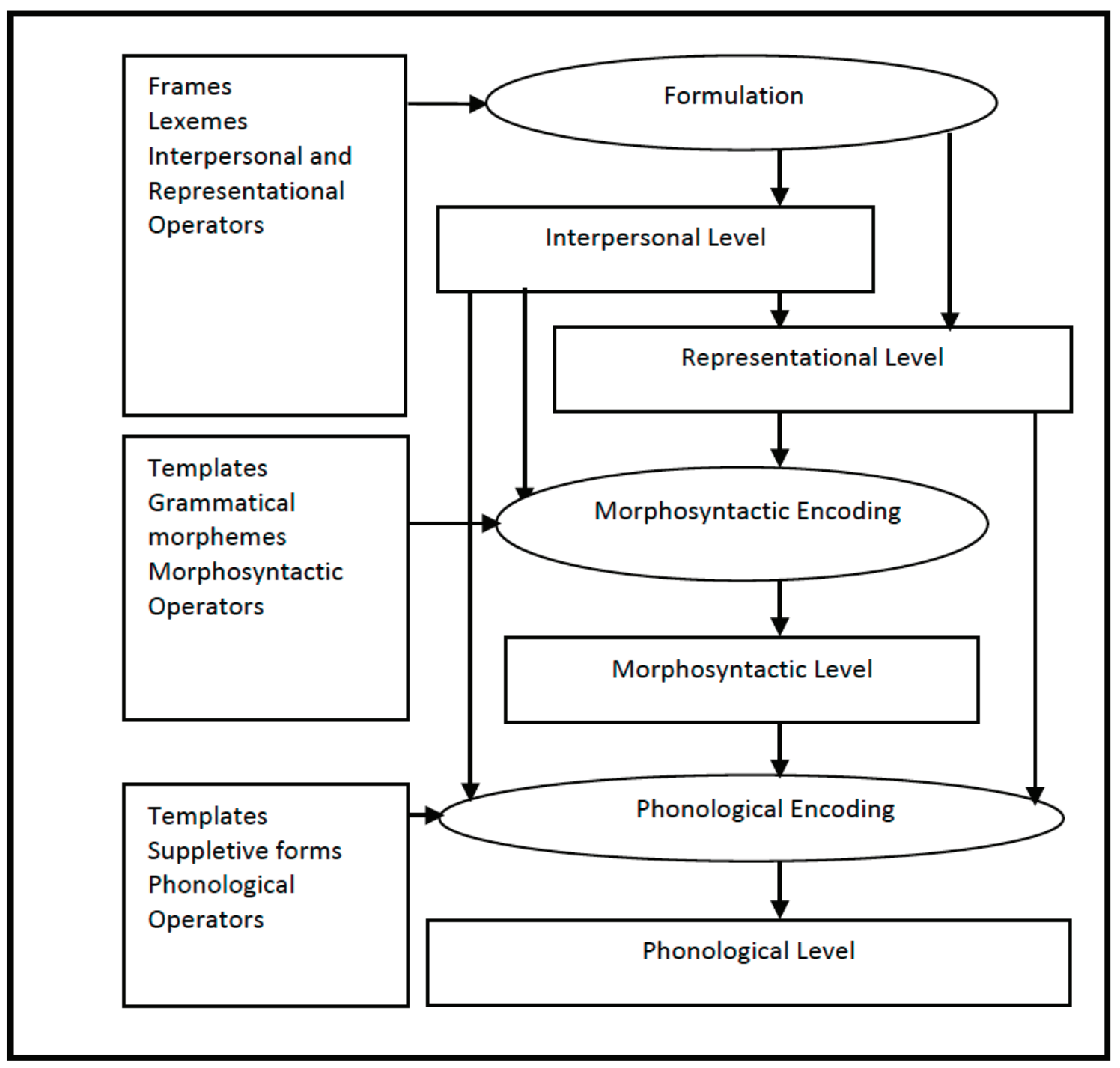

Figure 1. Outline of FDG

2 This section is partly based on Bastos et al. (2007).

3 Technical terms specific for FDG are capitalized throughout the text. 


\subsection{Levels}

The Interpersonal, Representational, and Morphosyntactic Levels of linguistic organization are constructed using different sets of primitives. Underlying the Interpersonal and Representational Levels of organization are pragmatic and semantic frames, which serve as hosts for lexemes and primary operators (operators that are defined in terms of their meaning). Underlying the Morphosyntactic Level are morphosyntactic templates, which receive, apart from lexical material from the preceding levels, grammatical words and morphosyntactic secondary operators (i.e. operators anticipating bound grammatical expressions). The Phonological Level is based on prosodic patterns, which host the lexical material handed over from the preceding levels, together with bound morphemes and possibly tertiary operators (i.e. operators anticipating the acoustic expression of the utterance).

Levels are related to each other through operations, represented with ovals in Figure 1. There is a crucial difference between Formulation on the one hand, and Encoding on the other. The process of Formulation deals with specifying the pragmatic and semantic configurations that can be encoded within the language. As far as Formulation is concerned, there may be differences between languages as regards the pragmatic and semantic functions that are necessary to describe their grammatical system. The process of Encoding deals with the morphosyntactic and phonological form pragmatic/semantic configurations take in a language. As far as Encoding is concerned, there may be differences between languages as regards their word order, phoneme inventory, morphological type, etc.

The levels that are most relevant for the current paper are the Interpersonal Level and the Representational Level. These will therefore be presented in somewhat more detail.

The Interpersonal Level is organized hierarchically as indicated in (1):

$$
\left(M_{1}:\left(A_{1}:\left[\left(F_{1}\right)\left(P_{1}\right)_{S}\left(P_{2}\right)_{A}\left(C_{1}:\left[\ldots\left(T_{1}\right)\left(R_{1}\right) \ldots\right]\left(C_{1}\right)\right)\right]\left(A_{1}\right)\right)\left(M_{1}\right)\right)
$$

The highest unit of analysis at the Interpersonal Level is the Move (M), which may contain one or more Discourse Acts (A). The central organizing unit within the Discourse Act is the basic Illocution (F), which takes the speech act Participants (P, the speaker $\mathrm{S}$ and the addressee A) and the Communicated Content (C) as its arguments. The Communicated Content itself is built up on the basis of a varying number of Ascriptive (T) and Referential (R) Subacts. The latter two units are operative at the same layer, which means that there is no hierarchical relation between them. The Interpersonal Level is thus an actional level, at which units are analysed in terms of their communicative function.

The Representational Level is organized hierarchically as indicated in (2):

$$
\left(\mathrm{p}_{1}:\left(\mathrm{ep}_{1}:\left(\mathrm{e}_{1}:\left(\mathrm{f}_{1}^{\mathrm{c}}:\left[\left(\mathrm{f}_{1}^{\mathrm{l}}\right)\left(\mathrm{x}_{1}\right)\right]\left(\mathrm{f}_{1}^{\mathrm{c}}\right)\right)\left(\mathrm{e}_{1}\right)\right)\left(\mathrm{ep}_{1}\right)\right)\left(\mathrm{p}_{1}\right)\right)
$$

The linguistic units that are relevant at this level are categorized in terms of the semantic categories they designate. Propositional Contents (p) are mental constructs, only existing in the mind; Episodes (ep) are thematically coherent combinations of States-of-Affairs, where the States-of-Affairs show unity or continuity in time, space, and participants; States-of-Affairs (e) themselves are events or states, which have a temporal reality; Individuals $(\mathrm{x})$ are concrete, tangible, entities that exist in space; and Properties (f) are special in that they only exist when they are applied to some other semantic category. Properties (f) occur both as units characterizing States-of-Affairs (the Configurational (c) Property $\left(\mathrm{f}_{1}^{\mathrm{c}}\right)$ in (2)), and as an independent unit (the Lexical (l) Property $\left(\mathrm{f}_{1}\right)$ ) within the Configurational Property. The units $\left(\mathrm{f}_{1}\right)$ and $\left(\mathrm{x}_{1}\right)$ in (2) are operative at the same layer, which means that there is no hierarchical relation between them. 


\subsection{Layering}

Each level is organized hierarchically in terms of several layers. Higher layers contain lower layers. All layers at the Interpersonal and Representational Levels have the following general structure, where $\alpha$ ranges over all variables:

$$
\left(\pi \alpha_{1}:[(\text { complex }) \text { head }]\left(\alpha_{1}\right): \sigma\left(\alpha_{1}\right)\right)_{\varphi}
$$

Lexical and grammatical means are used to build up each unit. Lexical means are the heads and optional modifiers $(\sigma)$, where the head is shown as the first restrictor and the modifier as a non-first restrictor. Grammatical means are operators $(\pi)$ and functions $(\varphi)$. Operators specify non-relational properties expressed grammatically, functions specify relational properties expressed grammatically.

The most important semantic domains of operators and modifiers for each of the layers of the Interpersonal and Representational Levels are given in Table 1. They are illustrated with examples of modifiers, as these will play an important role below.

Table 1. Semantic domains of operators and modifiers

\begin{tabular}{ll} 
Interpersonal level \\
\hline M & Communicative status of the move (e.g. in sum) \\
A & Communicative status of the act (e.g. in addition); Stylistic properties of the act (e.g. briefly) \\
F & Illocutionary manner (e.g. frankly) \\
C & Subjective attitude (e.g. fortunately); Reportativity (e.g. reportedly) \\
\hline Representational level \\
\hline p & Propositional attitude (e.g. possibly); Evidence (e.g. apparently) \\
ep & Order of episodes (e.g. first); Absolute time (e.g. yesterday) \\
e & Relative time (e.g. after that); Reality status (e.g. hardly); Event quantification (e.g. twice) \\
$\mathrm{f}$ & Manner (e.g. beautifully); Aspect (e.g. continuously) \\
\hline
\end{tabular}

In order to illustrate the above, example (5), adapted from Hengeveld \& Wanders (2007: 217) is formalized interpersonally (5) and representationally (6) below:

(4) Reportedly a man was slowly cutting himself with a knife yesterday.

(5) $\quad\left(\mathrm{A}_{\mathrm{I}}:\left[\left(\mathrm{F}_{\mathrm{I}}: \operatorname{DECL}\left(\mathrm{F}_{\mathrm{I}}\right)\right)\left(\mathrm{P}_{\mathrm{I}}\right)_{\mathrm{S}}\left(\mathrm{P}_{\mathrm{J}}\right)_{\mathrm{A}}\left(\mathrm{C}_{\mathrm{I}}:\left[\left(\mathrm{T}_{\mathrm{I}}\right)\left(\mathrm{R}_{\mathrm{I}}\right)\left(\mathrm{R}_{\mathrm{J}}\right)\left(\mathrm{R}_{\mathrm{K}}\right)\right]\left(\mathrm{C}_{\mathrm{I}}\right)\right.\right.\right.$ : reportedly rdv $\left.\left.\left._{\mathrm{A}}\left(\mathrm{C}_{\mathrm{I}}\right)\right)\right]\left(\mathrm{A}_{\mathrm{I}}\right)\right)$

(6) $\quad\left(\mathrm{p}_{\mathrm{i}}:\left(\operatorname{past~ep}_{\mathrm{i}}:\left(\operatorname{sim~e}_{\mathrm{i}}:\left(\operatorname{progr} \mathrm{f}_{\mathrm{i}}^{\mathrm{c}}:\left[\left(\mathrm{f}_{\mathrm{i}}: \operatorname{cut}_{\mathrm{V}}\left(\mathrm{f}_{\mathrm{i}}\right): \operatorname{slowly}_{\mathrm{Adv}}\left(\mathrm{f}_{\mathrm{i}}\right)\right)\left(1 \mathrm{x}_{\mathrm{i}}: \operatorname{man}_{\mathrm{N}}\left(\mathrm{x}_{\mathrm{i}}\right)\right)_{\mathrm{Ag}}\left(\mathrm{x}_{\mathrm{i}}\right)_{\text {Pat }}\right]\left(\mathrm{f}_{\mathrm{i}}^{\mathrm{c}}\right):\left(1 \mathrm{x}_{\mathrm{j}}: \operatorname{knife}_{\mathrm{N}}\right.\right.\right.\right.\right.$ $\left.\left.\left.\left(\mathrm{x}_{\mathrm{j}}\right)\right)_{\text {Instr }}\left(\mathrm{f}_{\mathrm{i}}^{\mathrm{c}}\right)\right)\left(\mathrm{e}_{\mathrm{i}}\right)\right)\left(\mathrm{ep}_{\mathrm{i}}\right)$ : yesterday Adv $\left.\left(\mathrm{ep}_{\mathrm{i}}\right)\left(\mathrm{p}_{\mathrm{i}}\right)\right)$

The different lexical modifiers (reportedly, slowly, with a knife, yesterday) are represented at their corresponding layers: reportedly modifies the C-layer at the Interpersonal Level in (5), deliberately, with a knife, and yesterday modify the $\mathrm{f}_{\mathrm{i}_{\mathrm{i}}}, \mathrm{f}_{\mathrm{i}_{\mathrm{i}}}$, and ep $\mathrm{p}_{\mathrm{i}}$-layers of the Representational Level in (6). An aspectual and a temporal operator at the $\mathrm{f}_{\mathrm{i}}$ - and $\mathrm{ep}_{\mathrm{i}}$ - layer in (6) trigger the past progressive form of the verb. 


\subsection{Complementation}

In the preceding paragraphs it was shown that layers may be qualified in similar ways by either operators or modifiers. In the same way, they may be used as arguments of complement-taking predicates, and these then again qualify the layers they take as their arguments in similar ways as operators and modifiers.

Thus, complement-taking verbs with meanings parallel to the ones listed in Table 1 for the Interpersonal and Representational Levels, take arguments with systematically decreasing internal complexity the lower the specific layer they embed. As a consequence, the layers listed in (7) and (8), taken from Hengeveld \& Mackenzie (2008, chapter 4), may occur as arguments of complement-taking predicates:

$$
\text { Interpersonal layers underlying subordinate clauses }
$$

$\begin{array}{lrrll}\mathrm{a} & \left(\Pi \mathrm{M}_{1}:\right. & \left(\Pi \mathrm{A}_{1}:\left[\ldots\left(\Pi \mathrm{C}_{1}:\right.\right.\right. & {\left[\left(\mathrm{T}_{1}\right)\left(\mathrm{R}_{1}\right)\right]} & \left.\left.\left.\left.\left(\mathrm{C}_{1}\right): \Sigma\left(\mathrm{C}_{1}\right)\right)\right]\left(\mathrm{A}_{1}\right): \Sigma\left(\mathrm{A}_{1}\right)\right)\left(\mathrm{M}_{1}\right): \Sigma\left(\mathrm{M}_{1}\right)\right) \\ \mathrm{b} & \left(\Pi \mathrm{A}_{1}:\left[\ldots\left(\Pi \mathrm{C}_{1}:\right.\right.\right. & {\left[\left(\mathrm{T}_{1}\right)\left(\mathrm{R}_{1}\right)\right]} & \left.\left.\left.\left(\mathrm{C}_{1}\right): \Sigma\left(\mathrm{C}_{1}\right)\right)\right]\left(\mathrm{A}_{1}\right): \Sigma\left(\mathrm{A}_{1}\right)\right) \\ \mathrm{c} & \left(\Pi \mathrm{C}_{1}:\right. & {\left[\left(\mathrm{T}_{1}\right)\left(\mathrm{R}_{1}\right)\right]} & \left.\left(\mathrm{C}_{1}\right): \Sigma\left(\mathrm{C}_{1}\right)\right)\end{array}$

(8) Representational layers underlying subordinate clauses

$$
\begin{array}{lllll}
\mathrm{a} & \left(\pi \mathrm{p}_{1}:\right. & \left(\pi \mathrm{ep}_{1}:\right. & \left(\pi \mathrm{e}_{1}:\right. & \left.\left.\left.\left(\pi \mathrm{f}_{1}^{\mathrm{c}}:\left[\left(\mathrm{f}_{1}\right)\left(\mathrm{x}_{1}\right)\right]\left(\mathrm{f}_{\mathrm{c}}^{\mathrm{c}}\right): \sigma\left(\mathrm{f}_{1}^{\mathrm{c}}\right)\right)\left(\mathrm{e}_{1}\right): \sigma\left(\mathrm{e}_{1}\right)\right)\left(\mathrm{ep}_{1}\right): \sigma\left(e \mathrm{p}_{1}\right)\right)\left(\mathrm{p}_{1}\right)\right) \\
\mathrm{b} & & \left(\pi \mathrm{ep}_{1}:\right. & \left(\pi \mathrm{e}_{1}:\right. & \left.\left.\left(\pi \mathrm{f}_{1}^{\mathrm{c}}:\left[\left(\mathrm{f}_{1}\right)\left(\mathrm{x}_{1}\right)\right]\left(\mathrm{f}_{\mathrm{c}}^{\mathrm{c}}\right): \sigma\left(\mathrm{f}_{1}^{\mathrm{c}}\right)\right)\left(\mathrm{e}_{1}\right): \sigma\left(\mathrm{e}_{1}\right)\right)\left(\mathrm{ep}_{1}\right): \sigma\left(e \mathrm{p}_{1}\right)\right) \\
\mathrm{c} & & \left(\pi \mathrm{e}_{1}:\right. & \left.\left(\pi \mathrm{f}_{1}^{\mathrm{c}}:\left[\left(\mathrm{f}_{1}\right)\left(\mathrm{x}_{1}\right)\right]\left(\mathrm{f}_{1}^{\mathrm{c}}\right): \sigma\left(\mathrm{f}_{1}^{\mathrm{c}}\right)\right)\left(\mathrm{e}_{1}\right): \sigma\left(\mathrm{e}_{1}\right)\right) \\
\mathrm{d} & & & \left(\pi \mathrm{f}_{1}^{\mathrm{c}}:\left[\left(\mathrm{f}_{1}\right)\left(\mathrm{x}_{1}\right)\right]\left(\mathrm{f}_{1}^{\mathrm{c}}\right): \sigma\left(\mathrm{f}_{1}^{\mathrm{c}}\right)\right)
\end{array}
$$

Lower layers are contained within higher layers. Therefore, subordinate clauses may be classified in terms of the highest layer they contain. In addition, as a layer always brings along its particular set of operators and modifiers, it may be predicted that all the operators and modifiers qualifying the highest layer underlying a certain type of subordinate clause, and all lower operators and modifiers, may be expressed in such a subordinate clause. On the other hand, modifiers and operators qualifying layers higher than the highest layer underlying a certain type of subordinate clause, are excluded from expression in such as subordinate clause.

The following examples (see also Hengeveld \& Mackenzie 2008: 361-367) illustrate this for the Interpersonal Level:

(9) While it is difficult to make generalizations about such a diverse public, it is easy to conclude [that in sum, these actions have led to a net loss of vegetative cover relative to pre-settlement conditions, as well as a substantial change in the type of vegetation present. At the same time, public consciousness regarding the importance of urban vegetation has certainly risen in the last ten years, although how much of that awareness has translated into changed behavior vis a vis urban plants in Quito is an open question.] (Move)

$$
\begin{aligned}
& \left(\mathrm{f}_{1}: \text { conclude }_{\mathrm{v}}\left(\mathrm{f}_{1}\right)\right) \\
& \left(\mathrm{x}_{1}\right)_{\mathrm{A}} \\
& \quad\left(\mathrm{M}_{1}:\left[\left(\mathrm{A}_{1}\right),\left(\mathrm{A}_{2}\right) \ldots\right]\left(\mathrm{M}_{1}\right): \Sigma\left(\mathrm{M}_{1}\right)\right)_{\mathrm{U}}
\end{aligned}
$$

(10) I might add that, frankly speaking ( ${ }^{*}$ in sum), you’re going to have bigger problems than just raising capital. (Discourse Act)

$$
\begin{aligned}
& \left(\mathrm{f}_{1}: \operatorname{add}_{\mathrm{v}}\left(\mathrm{f}_{1}\right)\right) \\
& \quad\left(\mathrm{x}_{1}\right)_{\mathrm{A}} \\
& \quad\left(\mathrm{A}_{1}:\left[\operatorname{ILL}\left(\mathrm{P}_{1}\right)_{\mathrm{S}}\left(\mathrm{P}_{2}\right)_{\mathrm{A}}\left(\mathrm{C}_{1}:\left[\ldots\left(\mathrm{T}_{1}\right)\left(\mathrm{R}_{1}\right) \ldots\right]\left(\mathrm{C}_{1}\right)\right)\right]\left(\mathrm{A}_{1}\right): \Sigma\left(\mathrm{A}_{1}\right)\right)_{\mathrm{U}}
\end{aligned}
$$


(11) They further stated that the members are reportedly ( ${ }^{*}$ frankly speaking, ${ }^{*}$ in sum) considering to walk separate paths. (Communicated Content)

$$
\begin{aligned}
& \left(\mathrm{f}_{1}: \operatorname{state}_{\mathrm{V}}\left(\mathrm{f}_{1}\right)\right) \\
& \quad\left(\mathrm{x}_{1}\right)_{\mathrm{A}} \\
& \quad\left(\mathrm{C}_{1}:\left[\ldots\left(\mathrm{T}_{1}\right)\left(\mathrm{R}_{1}\right) \ldots\right]\left(\mathrm{C}_{1}\right): \Sigma\left(\mathrm{C}_{1}\right)\right)_{\mathrm{U}}
\end{aligned}
$$

The complement-taking predicate conclude in (9) takes a summarizing Move in an argumentative series as its argument. This Move is represented as the Undergoer (U) argument $\mathrm{M}_{1}$ of the verb conclude and is itself built up as a series of Discourse Acts. We can now explain the presence of the modifier in sum in the subordinate clause, as this is an M-modifier. The complement-taking predicate add in (10) has a single Discourse Act $\mathrm{A}_{1}$ as its argument, and this explains why it is possible that the A-modifier frankly speaking but not an M-modifier may be expressed within it. Finally, the complement-taking predicate state in (11) takes the Communicated Content $\mathrm{C}_{1}$ as its argument, and therefore may contain the $\mathrm{C}$-modifier reportedly, while the presence of an A-modifier or an M-modifier is not grammatical.

The same type of reasoning may be applied at the Representational Level. Consider the following examples and their underlying formalizations (Hengeveld \& Mackenzie 2008: chapter 4):

$$
\text { He believed that I had possibly gone too far. (Propositional Content) }
$$

$$
\begin{aligned}
& \left(f_{1}: \operatorname{believe}_{\mathrm{v}}\left(\mathrm{f}_{1}\right)\right) \\
& \quad\left(\mathrm{x}_{1}\right)_{\mathrm{A}} \\
& \left.\quad\left(\mathrm{p}_{1}:\left(\mathrm{ep}_{1}:\left(\mathrm{e}_{1}:\left(\mathrm{f}_{1}^{\mathrm{c}}:\left[\left(\mathrm{f}_{2}\right) \ldots\right]\right)\left(\mathrm{f}_{1}^{\mathrm{c}}\right)\right)\left(\mathrm{e}_{1}\right)\right)\left(\mathrm{ep}_{1}\right)\right)\left(\mathrm{p}_{1}\right): \sigma\left(\mathrm{p}_{1}\right)\right)_{\mathrm{U}}
\end{aligned}
$$

(13) It ends with him ( ${ }^{\star}$ possibly) breaking up with her and her running crying out into the hall when he returns from the war. (Episode)

$$
\begin{aligned}
& \left(\mathrm{f}_{1}: \operatorname{end}_{\mathrm{v}}\left(\mathrm{f}_{1}\right)\right) \\
& \quad\left(\mathrm{ep}_{1}:\left(\mathrm{e}_{1}:\left(\mathrm{f}_{1}^{\mathrm{c}}:\left[\left(\mathrm{f}_{2}\right) \ldots\right]\left(\mathrm{f}_{1}^{\mathrm{c}}\right)\right)\left(\mathrm{e}_{1}\right)\right),\left(\mathrm{e}_{2}:\left(\mathrm{f}_{2}^{\mathrm{c}}:\left[\left(\mathrm{f}_{3}\right) \ldots\right]\left(\mathrm{f}_{2}^{\mathrm{c}}\right)\right)\left(\mathrm{e}_{2}\right)\right)\left(\mathrm{ep}_{1}\right): \sigma\left(\mathrm{ep}_{1}\right)\right)_{\mathrm{U}}
\end{aligned}
$$

(14) I saw her ( ${ }^{\star}$ possibly) leave before dinner ( ${ }^{\star}$ yesterday). (State-of-Affairs)

$$
\begin{aligned}
& \left(\mathrm{f}_{1}: \operatorname{see}_{\mathrm{V}}\left(\mathrm{f}_{1}\right)\right) \\
& \quad\left(\mathrm{x}_{1}\right)_{\mathrm{A}} \\
& \quad\left(\mathrm{e}_{1}:\left(\mathrm{f}_{1}^{\mathrm{c}}:\left[\left(\mathrm{f}_{2}\right) \ldots\right]\left(\mathrm{f}_{1}^{\mathrm{c}}\right)\right)\left(\mathrm{e}_{1}\right): \sigma\left(\mathrm{e}_{1}\right)\right)_{\mathrm{U}}
\end{aligned}
$$

(15) He continued to cry uninterruptedly $\left({ }^{*}\right.$ before dinner $/{ }^{\star}$ when he returns from the war $/{ }^{*}$ possibly). (configurational property)

$$
\begin{aligned}
& \left(\mathrm{f}_{1}: \text { continue }\left(\mathrm{f}_{1}\right)\right) \\
& \quad\left(\mathrm{x}_{1}\right)_{\mathrm{A}} \\
& \quad\left(\mathrm{f}_{1}^{\mathrm{c}}:\left[\left(\mathrm{f}_{2}\right) \ldots\right]\left(\mathrm{f}_{1}^{\mathrm{c}}\right): \sigma\left(\mathrm{f}_{1}^{\mathrm{c}}\right)\right)_{\mathrm{U}}
\end{aligned}
$$

The complement-taking predicate believe in (12) is the expression of a propositional attitude, and its argument therefore has to be a propositional content $\left(\mathrm{p}_{1}\right)$. For this reason it may contain the modifier possibly, which expresses a propositional attitude. The complement-taking predicate end_with in (13) takes an argument $\left(\mathrm{ep}_{1}\right)$ that denotes the final episode of a story. It may therefore contain an absolute temporal modifier, in this case when he returns from the war, but a p-modifier is not grammatical. The complement-taking predicate see in (14) takes the witnessed State-of-Affairs $\left(\mathrm{e}_{1}\right)$ as its argument. This explains the presence of the relative temporal modifier before dinner, and the fact that p-modifiers and ep-modifiers are not grammatical, at least not as modifiers of the subordinate clause. Finally, the complement-taking predicate continue in (15) 
denotes the persisting presence of a property, and it therefore takes a Configurational Property $\left(\mathrm{f}_{1}^{\mathrm{c}}\right)$ as its complement. The presence of this layer licenses the modification by the aspectual adverb uninterruptedly, while in the absence of higher layers p-modifiers, ep-modifiers, and e-modifiers are not grammatical, again when these are taken as modifiers of the subordinate rather than the main clause.

We conclude, then, that it is possible to classify complement clauses on the basis of the highest layer they contain. Since lower layers are included in higher layers, the presence of the highest layer predicts the presence of all lower layers as well as the operators and modifiers corresponding to them.

\section{Perception verbs in Functional Discourse Grammar}

\subsection{Introduction}

Perception verbs, like see and hear, specify a relation between an individual (the perceiving entity) and different kinds of the representational/interpersonal categories introduced above, according to the nature of what is perceived. In Dik and Hengeveld (1991), a description of the different kinds of perception verb complements is given within the Functional Grammar framework, accounting for the many subtle semantic differences between them. Drawing on earlier work by e.g. Kirsner \& Thompson (1976), Holierhoek (1980), Barwise \& Perry (1983), Noonan (1985), and van der Auwera (1985), the authors argue that perception verb complements can be understood in terms of the hierarchical clause structure used in Functional Grammar to represent utterances. In the same way, in this section we carry out the characterization of perception verbs and their complements, but now according to the FDG model, taking the previous description as our starting point. We will show that perception verbs can take five different types of complement: Properties (f), Individuals (x), States-of-Affairs (e), Episodes (ep), and Communicated Contents (C).

From this section onwards we will use Brazilian Portuguese examples. All these examples were obtained through internet searches using the Google search engine. They were subsequently checked for their grammaticality by the three authors of this paper that are native speakers of Brazilian Portuguese.

\subsection{Perception of Property}

A perception verb in this case describes the perception of a property by an individual. Since properties do not exist by themselves, the object of perception is a characteristic of another entity, as illustrated in $(16):^{4}$

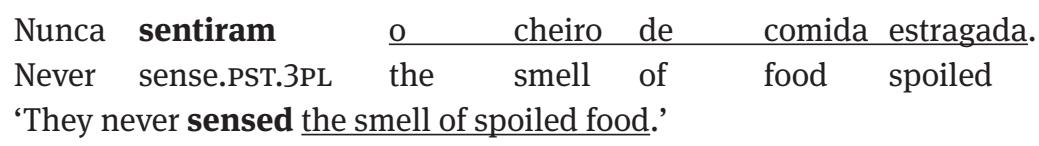

The verb sentir 'sense' in (16) specifies a relation between the perceiving Individual (x), the understood subject 'they', and the perceived Property (f) o cheiro de comida estragada 'the smell of spoiled food'.

\subsection{Perception of Individual}

In this use of perception verbs what is described is the perception of one individual by another, as illustrated in (17):

4 In Brazilian Portuguese examples and their translations we present the perception verb in bold and its complement through underlining. 


$\begin{array}{llll}\mathrm{Eu} & \mathbf{v i} & \mathrm{o} & \text { passarinho }\end{array}$

'I saw the little bird.'

In this case, the verb ver 'see' specifies a relation between two semantic categories of the same type: a perceiving Individual (x) eu 'I' and a perceived Individual (x) o passarinho 'the little bird', both individuals, and, consequently, concrete and tangible entities.

\subsection{Perception of State-of-Affairs}

This reading concerns the direct perception of a state-of-affairs by an individual, as the following example shows:

$\begin{array}{llllll}\text { Eu vi } & \text { o } & \text { carro } & \text { bater } & \text { numa } & \text { bike. } \\ \text { 1sG see.PST.1SG } & \text { the } & \text { car } & \text { crash.INF } & \text { in.a } & \text { bicycle } \\ \text { 'I saw the car crash into a bicycle.' } & & & & \end{array}$

In (18), the verb ver 'see' specifies a relation between the Individual (x) category eu 'I' and a directly perceived State-of-Affairs (e) um carro batendo numa bike 'a car crashing into a bicycle’.

\subsection{Perception of Episode}

The fourth possible reading concerns the deduction of a piece of knowledge by means of perception through one of the senses, as illustrated in the following sentence:

\begin{tabular}{|c|c|c|c|c|c|c|c|c|}
\hline $\mathrm{Eu}$ & vi & que & 0 & carro & tinha & batido & numa & bike. \\
\hline $1 \mathrm{sG}$ & see.PST.1sG & that & the & car & have.Ps & crash.PTCP & in.a & bike \\
\hline
\end{tabular}

As is clear from the tenses used, in this example the first person subject did not witness a car crashing into a bicycle directly, as in (18). Rather, he/she comes to the conclusion that the crash has taken place on the basis of visual evidence. The difference with (18) is that in (18) the complement clause represents the stateof-affairs witnessed directly and is thus of the e-type, while in (19) it represents the conclusion the speaker arrived at.

Dik \& Hengeveld (1991) call this type 'perception of propositional content'. We here choose, however, to classify it as the perception of Episodes, following Hengeveld \& Hattnher (2015). These authors situate the evidential category of deduction at the layer of the Episode, on the basis of the fact that 'deduction necessarily involves at least two related states-of-affairs: the perceived one and the deduced one. The speaker deduces the occurrence of one state-of-affairs, the deduced one, on the basis of another state-ofaffairs, the perceived one' (Hengeveld \& Hattnher 2015: 486). As it is within the Episode that the relation between States-of-Affairs is specified, deduction must then be situated at that layer.

The connection between the two States-of-Affairs within the Episode is also shown in the fact that there has to be a (relative) temporal connection between the perceived and the deduced events, as illustrated in (20) (Hengeveld \& Hattnher 2015: 490-491):

5 Note that perception of a Propositional Content is at stake in expressions such as I see what you mean. 
(20) a. I smell that he has been cooking.

b. $\quad{ }^{\star}$ I smell that he had been cooking.

The temporal specification in the complement clause in (20a) expresses relative tense, which connects the perceiving event with the deduced event. In (20b) the complement clause contains an expression of absolute tense, and thereby disconnects the perceiving event from the deduced event, which leads to ungrammaticality. Given the requirement of a temporal connection, the two events must be within a single Episode.

There are a number of grammatical differences between constructions that express the perception of a State-of-Affairs and those that express the perception of an Episode that allow us to distinguish them, as shown in Dik and Hengeveld (1991). These are: (i) the simultaneity of the e-complement with the main clause; (ii) the impossibility to negate the e-complement independently; and (iii) non-factivity, i.e., the absence of a presupposition on the part of the speaker that the e-category took place.

The first property is shown in (21):

$\begin{array}{llllllll}\star & \text { vi } & \text { o } & \text { carro } & \text { ter } & \text { batido } & \text { numa } & \text { bike. } \\ \text { 1SG see.PST.1SG } & \text { the } & \text { car } & \text { have.INF } & \text { crash.PTCP } & \text { into.a } & \text { bicycle } \\ \text { 'I saw the car having crashed into a bicycle.' } & & & & \end{array}$

While the use of the past tense is fine in (19), it leads to ungrammaticality in (21). This is because direct perception requires simultaneity of the perceiving and the perceived State-of-Affairs.

The examples in (22) show that a State-of-affairs complement cannot be negated, while an Episode complement can:

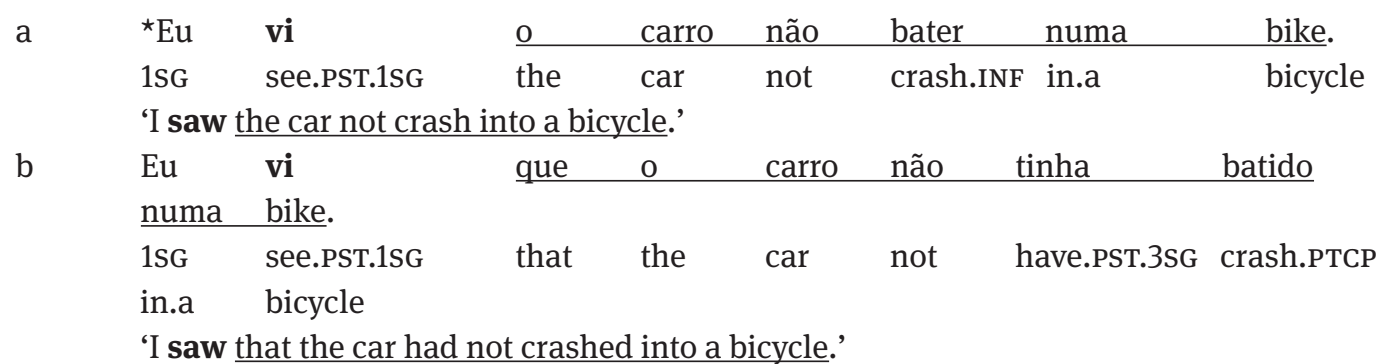

While negation of the complement is fine in (22b), it is not in (22a). The reason is that something that does not happen cannot be perceived directly.

Finally, the examples in (23) demonstrate that the truth of Episode complements is presupposed, while that of State-of-Affairs complements is not:

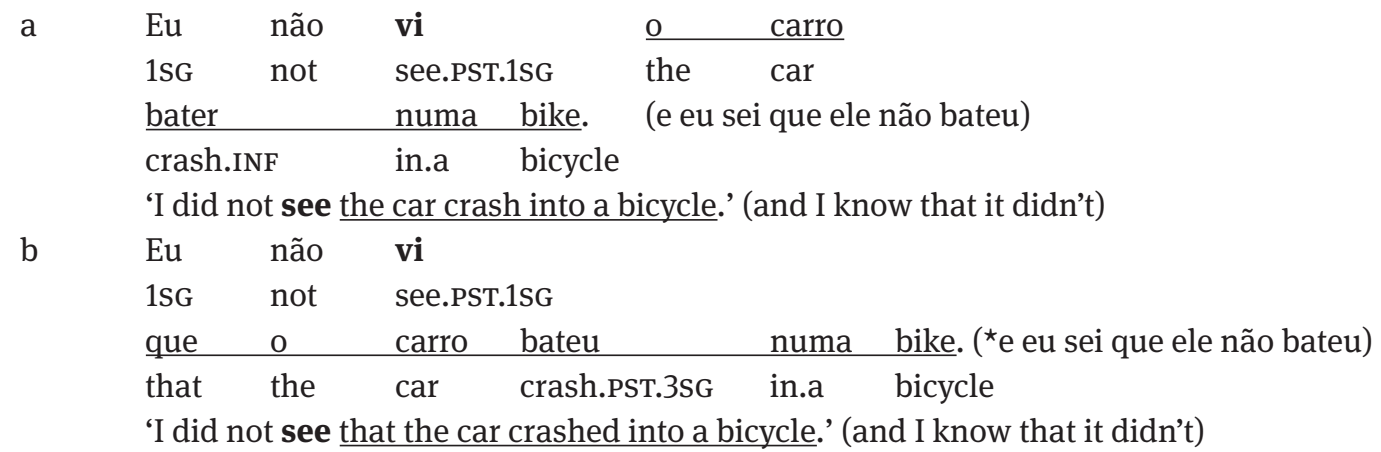


When the verb ver 'see' takes an Episode as its complement, it describes acquisition of knowledge. Predicates of acquisition of knowledge are semi-factive, that is, the speaker presupposes that the complement describes a fact. For this reason, the continuation in (23b) is ungrammatical.

\subsection{Perception of Communicated Content}

This reading is only possible with predicates of hearing and seeing (in the sense of 'reading') when used by the speaker to relay words or thoughts of someone else, as illustrated in (24):

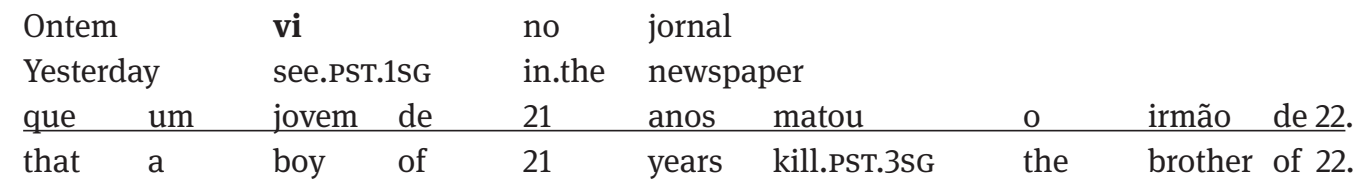

'Yesterday I saw in the newspaper that a 21-year-old boy killed his 22-year-old brother.'

In (24), the verb ver 'see' specifies a relation between the first person singular perceiving $\mathrm{x}$-type subject 'I' and the perceived Communicated Content que um jovem de 21 anos matou o irmão de 22 'that a 21 years old boy killed his brother of 22', which represents a piece of information claimed by a third party.

The grammatical expression of the perception of a Communicated Content is different from that of an Episode. As shown in (24), in the former case the source of the information, here $o$ jornal 'the newspaper', may be specified. In the latter case, this is not possible, as shown in (25):

\begin{tabular}{|c|c|c|c|}
\hline $\begin{array}{l}\text { Percebi } \\
\text { noted.PST.1SG }\end{array}$ & & $\begin{array}{l}\text { (pelas suas } \\
\text { (through 3.Poss }\end{array}$ & $\begin{array}{l}\text { ações/^pelo João) } \\
\text { actions/through João) }\end{array}$ \\
\hline ela & é & uma & pessoa muito legal. \\
\hline $3 \mathrm{SG}$ & $\mathrm{CO}$ & S.3SG & person very \\
\hline
\end{tabular}

\subsection{The representation of perception verbs in FDG}

Constructions with perception verbs, like the ones presented in 3.2 to 3.6, are used to express the subject's perception of an aspect of the extralinguistic world. In this way, this kind of construction is dealt with at the Representational Level in the FDG model. ${ }^{6}$ In this subsection we will present the underlying representations for the constructions with perception verbs presented so far. As shown before, perception verbs can have different representational or interpersonal categories as their complement, and these are represented by different variables. We may therefore formalize the differences between them exploiting the variables introduced earlier. 'PV' is shorthand for 'perception verb'.

(i) perception of Property:

(26) $\quad\left[\left(\mathrm{f}_{\mathrm{I}}: \mathrm{PV}\left(\mathrm{f}_{\mathrm{i}}\right)\right)\left(\mathrm{x}_{\mathrm{i}}\right)\left(\mathrm{f}_{\mathrm{j}}\right)\right]$

e.g. 'I $\left(\mathrm{x}_{\mathrm{i}}\right)$ saw $\left(\mathrm{f}_{\mathrm{i}}\right)$ the redness of her eyes $\left(\mathrm{f}_{\mathrm{j}}\right)$.'

(ii) perception of Individual:

$$
\begin{aligned}
& {\left[\left(\mathrm{f}_{\mathrm{i}}: \operatorname{PV}\left(\mathrm{f}_{\mathrm{i}}\right)\right)\left(\mathrm{x}_{\mathrm{i}}\right)\left(\mathrm{x}_{\mathrm{j}}\right)\right]} \\
& \text { e.g. 'I }\left(\mathrm{x}_{\mathrm{i}}\right) \text { saw }\left(\mathrm{f}_{\mathrm{i}}\right) \text { your brother }\left(\mathrm{x}_{\mathrm{j}}\right) .
\end{aligned}
$$

6 This is even so when the complement designates a Communicated Content, a unit at the Interpersonal Level. When Interpersonal units are being talked about, they enter the Representational Level, as described in Hengeveld \& Mackenzie 2008: $275-277$. 
(iii) perception of State-of-Affairs:

(28) $\quad\left[\left(f_{\mathrm{i}}: P V\left(f_{\mathrm{i}}\right)\right)\left(\mathrm{x}_{\mathrm{i}}\right)\left(\mathrm{e}_{\mathrm{i}}\right)\right]$

e.g. ' $I\left(x_{i}\right)$ saw $\left(f_{i}\right)$ him arrive $\left(e_{i}\right)$.'

(iv) perception of Episode

(29) $\quad\left[\left(\mathrm{f}_{\mathrm{i}}: \mathrm{PV}\left(\mathrm{f}_{\mathrm{i}}\right)\right)\left(\mathrm{x}_{\mathrm{i}}\right)(\mathrm{ep})\right]$

e.g. ' $I\left(\mathrm{x}_{\mathrm{i}}\right)$ saw $\left(\mathrm{f}_{\mathrm{i}}\right)$ that he had arrived $\left(\mathrm{ep}_{\mathrm{i}}\right)$.'

(v) perception of Communicated Content

(30) $\quad\left[\left(\mathrm{f}_{\mathrm{i}}: \mathrm{PV}\left(\mathrm{f}_{\mathrm{i}}\right)\right)\left(\mathrm{x}_{\mathrm{i}}\right)\left(\mathrm{C}_{\mathrm{I}}\right)\right]$

e.g. 'I $\left(\mathrm{x}_{\mathrm{i}}\right)$ hear $\left(\mathrm{f}_{\mathrm{i}}\right)$ you were fired $\left(\mathrm{C}_{\mathrm{I}}\right)$,'

In the representations from (26) to (29), the variables representing the perception verb complement pertain to the Representational Level. In (30), it belongs to the Interpersonal Level. This is due to the fact that, in this reading of perception verbs, the complement of the verb is the Communicated Content produced by a different speaker in an interpersonal act.

\section{Predictions}

After introducing the theoretical background and the classification of the complement types of perception verbs that follows from it, we now may formulate two predictions concerning the distribution of semantic complement types and their morphosyntactic expression.

Not all perception verbs may occur with all five semantic complement types introduced above. For instance, the verb ver 'see' was used above to illustrate all five complement types, as it is compatible with all of them. Other verbs, however, such as provar 'taste' have a much more limited range of possibilities. This particular verb only occurs with f-complements and x-complements, shown in (31):

a.

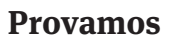

o sabor de doce

taste of sweet leite.

taste.PST.3PL

the

'We tasted the taste of sweet condensed milk.'

b.

$\begin{array}{ll}\text { de leite. } & \\ \text { of milk }\end{array}$

$\begin{array}{llll}\text { taste.PST.3PL the famous cake of.the Café } & \text { Sacher } \\ \text { 'We tasted the famous cake of Café Sacher, } & & \end{array}$

The question is now whether there is any systematicity in the distribution of semantic complement types across perception verbs. We expect that there is. Our prediction is that it is likely for perception verbs to take complements based on lower layers, while it becomes more unlikely for them to take complements based on higher layers. The reason is that basic perception is a physical process, and that the higher one gets in terms of layering, the less concrete and the more abstract the layers become. We thus predict that individual perception verbs will take semantic complement types according to the following implicational hierarchy:

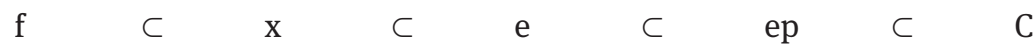

That is, if a certain perception verb allows a complement of, say, the ep-type, it will also allow all the complement types to the left of ep in the hierarchy. And if it does not allow, for instance, a complement of the $x$-type, it won't allow all the complement types to the right of $x$ either. There may be a diachronic 
dimension to this as well, as it might be that perception verbs start out with lower layer complements and expand the range of complements over time passing along the hierarchy.

Turning now to the morphosyntactic expression of perception verb complements, the question is whether we can also predict how the different morphosyntactic types of complement are distributed across the different semantic types. As has become clear in the various examples shown above, complements may take the form of noun phrases, non-finite clauses (infinitival and progressive), and finite clauses. As shown in earlier work (Hengeveld 1998), the higher the layer a subordinate clause contains, the more likely it is to be expressed by a finite construction. The reason for this is that, as the number of layers increases, the number of grammatical categories to be expressed also increases. We may thus expect the following mapping between the semantic types of complement represented in (32) and their morphosyntactic expression:

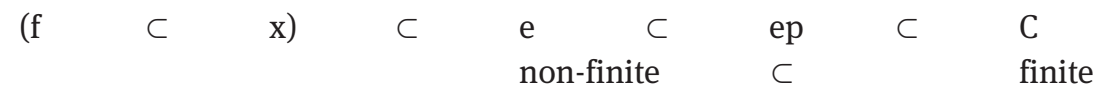

As f-complements and x-complements may only be expressed by noun phrases, they are not relevant categories to test this prediction. For the remaining types of semantic complement (33) predicts two things. First, finite complements are more likely to be found to the right of the hierarchy and non-finite complements are more likely to be found to the left of the hierarchy. And secondly, when a category to the right in the hierarchy is expressed by non-finite forms, then the categories to the left of it are also expressed by these forms; and when a category to the left in the hierarchy is expressed by finite forms, then the categories to the right of it are also expressed by these forms.

In the following we go into the semantics of perception verbs and their complements in Section 5 before testing the first prediction in Section 6. We then describe the morphosyntax of perception verb complements in Section 7, and test the second prediction in Section 8.

\section{The semantics of perception verbs and their complements in Brazilian Portuguese ${ }^{7}$}

The Brazilian Portuguese perception verbs investigated in this paper are the following:

(i) visual perception: olhar 'look', avistar 'catch sight of', visualizar 'visualize', ver 'see', perceber 'perceive', observar 'observe', and notar 'notice';

(ii) auditory perception: escutar 'listen', ouvir 'hear', ver 'see', perceber 'perceive', observar 'observe', notar 'notice';

(iii) olfactory perception: cheirar 'smell', perceber 'perceive', sentir 'sense', experimentar 'try'.

(iv) gustatory perception: experimentar 'try', degustar 'taste', provar 'try/taste, saborear 'savor', sentir 'sense', perceber 'perceive';

(v) tactile perception: tocar 'touch', apalpar 'touch', palpar 'touch', sentir 'feel', tatear 'touch', perceber 'perceive';

As can be noted in this listing, there are quite a number of perception verbs that can be used to express perception through various senses. For instance, the verb experimentar 'try' can be used for olfactory and gustatory perception, the verb perceber 'perceive' for all five senses. The distribution of the perceptual modalities covered by these verbs does not seem to be random, as Table 2 shows.

Especially remarkable is that in three cases the same verb may be used to express visual and auditory perception. A typological study by Viberg (1984) shows that it is uncommon for languages to not express visual perception by a separate lexical item, a situation which occurs in only three of his 53 languages. In

7 Earlier work on perception verbs in Brazilian Portuguese includes Barros (1977), Carvalho (2004), and Vendrame (2010). 
Table 2. The semantic distribution of perception verbs in Brazilian Portuguese

\begin{tabular}{l|l|l|l|l}
\hline Visual perception & \multicolumn{1}{l}{ Auditory perception } & \multicolumn{1}{l}{ Olfactory perception } & \multicolumn{1}{l}{ Gustatory perception } & \multicolumn{1}{l}{ Tactile perception } \\
\hline $\begin{array}{l}\text { Avistar, Olhar, } \\
\text { Visualizar }\end{array}$ & Escutar, Ouvir & Cheirar & $\begin{array}{l}\text { Degustar, } \\
\text { Provar, Saborear }\end{array}$ & $\begin{array}{l}\text { Apalpar, } \\
\text { Palpar, }\end{array}$ \\
\hline Observar, Notar, Ver & & & Tocar \\
\hline & Experimentar & \\
\cline { 3 - 5 } & Sentir & \\
\hline Perceber
\end{tabular}

none of Viberg's three cases does the polysemy ${ }^{8}$ exhibited concern just visual and auditory perception. Aikhenvald \& Storch (2013: 16) already noted a number of cases like these, and in Brazilian Portuguese this type of polysemy is found as well, though it is restricted to the perception of properties. Examples (34)-(36) show the use of ver 'see', observar 'observe', and notar 'note' to express visual perception:

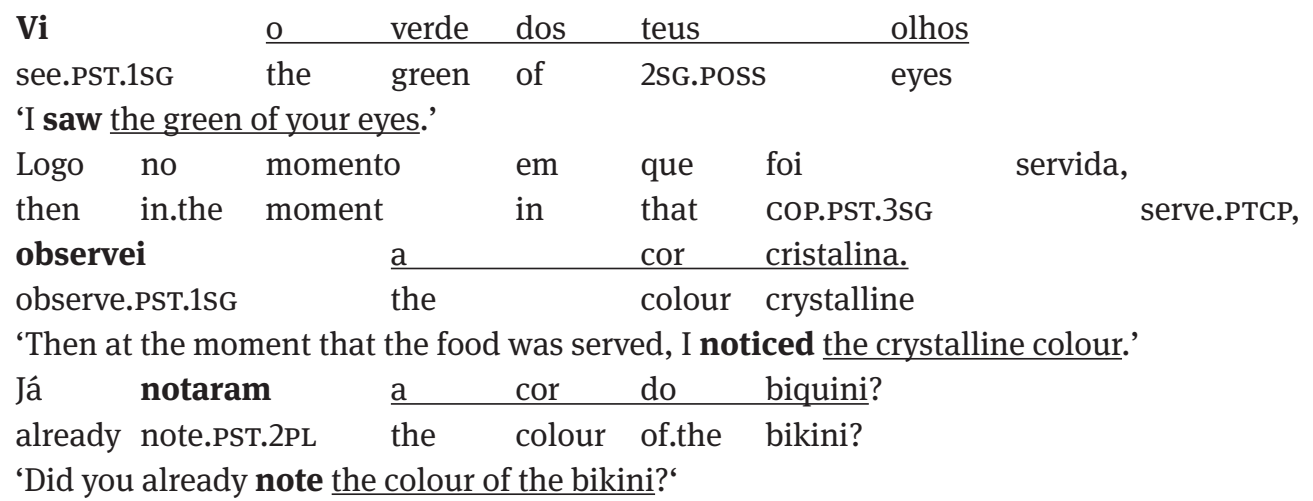

Examples (37)-(39) show the use of those same verbs to express auditory perception:

$\begin{array}{lllll}\text { Vi } & \text { um } & \text { barulho } & \text { de } & \text { carro. } \\ \text { see.PST.1SG } & \text { a } & \text { noise } & \text { of } & \text { car }\end{array}$

'I heard the noise of a car.'

\begin{tabular}{lllll}
$\begin{array}{l}\text { Observei } \\
\text { observe.PST.1SG }\end{array}$ & um & barulho & na & transmissão. \\
\hline
\end{tabular}

'I observed a noise in the transmission.'

$\begin{array}{lllllll}\text { Assim que notei } & \text { nom } & \text { o } & \text { barulho, } & \text { com } & 500 \mathrm{~km} \text {, } \\ \text { such that } & \text { note.PST.1sG } & \text { the } & \text { noise, } & \text { after } & 500 \mathrm{~km} \text {, } \\ \text { levei } & \text { o carro } & & \text { na } & \text { concessionária. } \\ \text { take.PST.1SG } & \text { the car } & & \text { in.the } & \text { dealer } & \end{array}$

'As soon as I noted the noise, after $500 \mathrm{~km}$, I took the car to the dealer.'

Given the extensive amount of polysemy observed, where necessary we will indicate with a superscript which reading of a perception verb is intended. Thus $v e{ }^{A}$ will mean that the verb ver 'see' is used in its auditory reading. ${ }^{9}$

\section{The distribution of semantic complement types}

In Section 4 we predicted that perception verbs take different sets of semantic complement types according to the following hierarchy:
(40)
f
$\subset \quad \mathrm{x}$
$\subset \mathrm{e}$
ᄃ
ep
c
C

8 For the question of polysemy in perception verbs, see also the discussion in Gisborne (2010).

9 The abbreviations used are A for auditory, G for gustatory, O for olfactory, T for tactile, and V for visual. 
This hierarchy predicts that semantic complement types more to the left of the hierarchy are implied by the presence of semantic complement types more to the right of the hierarchy. Table 3 shows that this prediction is fully borne out by the data. The data on which this table is based are all given in Appendix 1 . Note that a ' + ' in Table 3 indicates that a particular complement type is attested, while a blank indicates that it was not attested.

At the top of Table 3 the perception verbs with the widest range of semantic complement types are given, at the bottom those with the narrowest range are given. The verbs at the top combine with all possible complement types, the ones at the bottom only with the property denoting complement type, the lowest one on the hierarchy. All intermediate cases show systematic decreasing combinatorial possibilities following the various steps in hierarchy (40).

The verbs highest on the hierarchy are verbs of visual and auditory perception taking a C-complement. This is not surprising, as linguistic units can only be perceived through reading and listening, i.e. through visual and auditory perception. At the other end of the hierarchy we find verbs with a primary visual reading being used in an auditory sense. We do not see an evident explanation for this fact. In between we find other sets of combinations of perception verbs with semantic complement types, but importantly these always obey the hierarchy in (40). Our first prediction is thus fully borne out.

Table 3. The distribution of semantic complement types

\begin{tabular}{|c|c|c|c|c|c|}
\hline & Property & Individual & State-of-Affairs & Episode & Communicated content \\
\hline Escutar $^{A}$ & + & + & + & + & + \\
\hline Ouvir ${ }^{A}$ & + & + & + & + & + \\
\hline $\operatorname{Ver}^{v}$ & + & + & + & + & + \\
\hline Avistar ${ }^{v}$ & + & + & + & + & \\
\hline Notar $^{v}$ & + & + & + & + & \\
\hline Observar ${ }^{v}$ & + & + & + & + & \\
\hline Perceber ${ }^{\vee}$ & + & + & + & + & \\
\hline Perceber $^{6}$ & + & + & + & + & \\
\hline Perceber $^{\top}$ & + & + & + & + & \\
\hline Perceber ${ }^{0}$ & + & + & + & + & \\
\hline Sentir ${ }^{6}$ & + & + & + & + & \\
\hline Sentir ${ }^{\top}$ & + & + & + & + & \\
\hline Sentir ${ }^{0}$ & + & + & + & + & \\
\hline Visualizar ${ }^{\vee}$ & + & + & + & + & \\
\hline Olhar ${ }^{v}$ & + & + & + & & \\
\hline$V_{e}{ }^{A}$ & + & + & + & & \\
\hline Experimentar ${ }^{6}$ & + & + & & & \\
\hline Provar $^{6}$ & + & + & & & \\
\hline Degustar $^{6}$ & + & + & & & \\
\hline Saborear ${ }^{6}$ & + & + & & & \\
\hline Tocar $^{\top}$ & + & + & & & \\
\hline Apalpar ${ }^{\top}$ & + & + & & & \\
\hline Palpar $^{\top}$ & + & + & & & \\
\hline Tatear & + & + & & & \\
\hline Cheirar $^{0}$ & + & + & & & \\
\hline Experimentar ${ }^{\circ}$ & + & + & & & \\
\hline Observar ${ }^{A}$ & + & & & & \\
\hline Notar $^{A}$ & + & & & & \\
\hline Perceber $^{A}$ & + & & & & \\
\hline
\end{tabular}




\section{The morphosyntax of perception verbs in Brazilian Portuguese}

The perception verbs analyzed in this paper allow various types of morphosyntactic complement. The first division is between noun phrase complements and clausal complements. Within the group of clausal complements we find finite and non-finite clauses, and the latter group consists of progressive and infinitival clauses.

$$
\begin{array}{lll}
\text { Morposyntactic types of complement of perception verbs } \\
\begin{array}{ll}
\text { Noun phrase } \\
\text { Clause }
\end{array} & \text { Finite } & \\
& \text { Non-finite } & \text { Infinitival } \\
& & \text { Progressive }
\end{array}
$$

Examples (42)-(45) illustrate the various types of complement: a noun phrase in (42), a finite clause in (43), infinitival complements in (44), and a progressive complement in (45).

$$
\text { Vi }
$$

see.PST.1SG

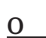

verde

dos

teus olhos.

'I saw the green of your eyes.'

$\begin{array}{llllll}\text { Quando } & \text { pego } & 0 & & \\ \text { when } & \text { take.PRs.1SG } & \begin{array}{l}\text { telephone } \\ \text { the phone }\end{array} & & \\ \text { ouço } & \text { que o } & \text { modem não entra } & \text { na } & \text { linha. } \\ \text { hear.PRS.1SG } & \text { that the } & \text { modem not enter.PRS.3SG } & \text { in.the line }\end{array}$

(44)

'When I take the phone I hear that the modem doesn't connect.'

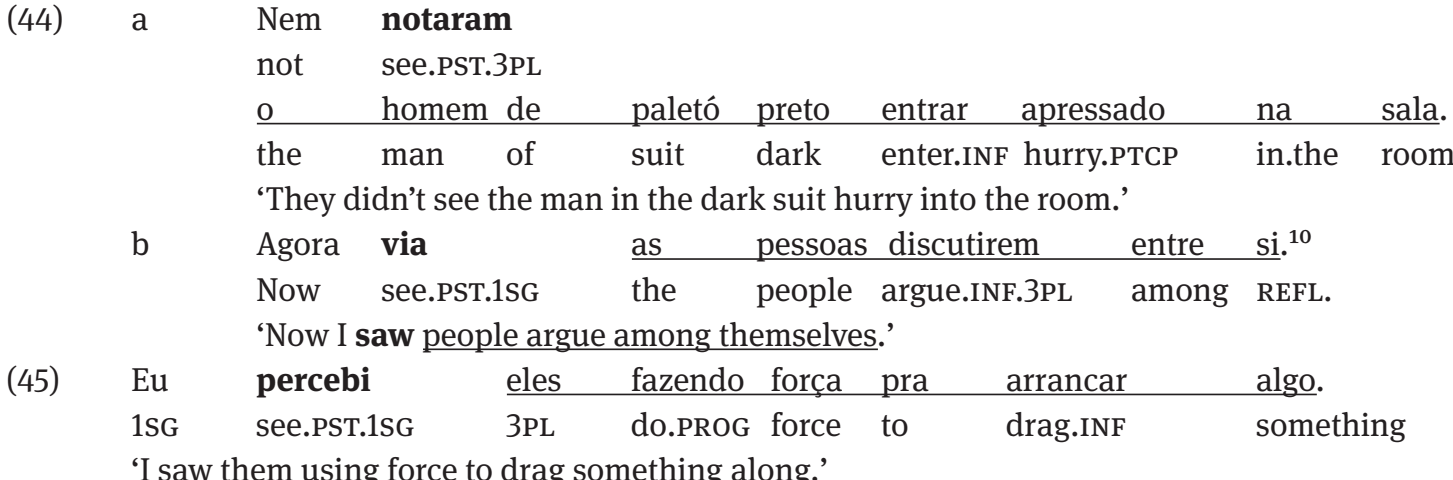

Nominal complements may express all possible semantic complement types. In the following examples the complement designates a Property (46), an Individual (47), a State-of-Affairs (48), an Episode (49), and a Communicated Content (50):

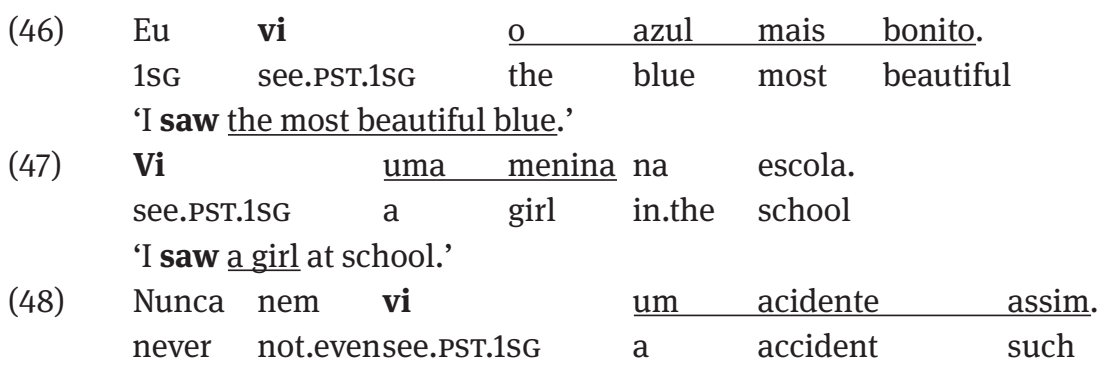

10 Under certain circumstances, which are irrelevant to our purposes here, the infinitive may receive person inflection, as shown in (44b). 
'I never saw an accident like that.'

$\begin{array}{llllll}\text { E } & \text { então } & \text { eu } & \text { vi } & \text { sua } & \text { intenção. } \\ \text { and } & \text { then } & \text { 1sG } & \text { see.PST.1SG } & \text { 2sG.POSS } & \text { intention }\end{array}$

'And then I saw your intention.'

$\begin{array}{llllll}\text { Vi } & \text { uma } & \text { mensagem } & \text { no } & \text { celular } & \text { dele } \\ \text { see.PST.1sG a } & \text { message } & \text { on } & \text { cell phone } & \text { 3sG.POSS } \\ \text { e } & \text { acho } & & \text { que ele } & \text { me } & \text { traiu. } \\ \text { and think.PRS.1SG } & \text { that 3SG } & \text { 1SG.OBL } & \text { cheat.PST.3SG }\end{array}$

'I saw a message on his cell phone and I think he cheated on me.'

The other way round, complements designating a Property or an Individual cannot be expressed by clauses. They can of course be expressed by headless relatives, as in (51), but these are just another manifestation of noun phrases:

(51) Vi

$\begin{array}{lllll}\text { Vi } & \text { o } & \text { que } & \text { queria } & \text { ver. } \\ \text { see.PST.1SG } & \text { the } & \text { what } & \text { want.PST.1SG } & \text { see.INF } \\ \text { 'I saw what I wanted to see.' } & & \end{array}$

\section{The distribution of morphosyntactic complement types}

In Section 4 we predicted the following distribution of morphosyntactic complement types with perception verbs in Brazilian Portuguese:

$$
\begin{aligned}
& \begin{array}{llllllllllllllll}
(\mathrm{f} & \subset & \mathrm{x}) & \subset & \text { e } & \subset & \text { ep } & \subset & \mathrm{C}
\end{array} \\
& \text { non-finite } \quad \subset \quad \text { finite }
\end{aligned}
$$

This prediction follows from the idea that the higher the layer on which the semantic complement type is based, the more likely it is that this complement type will be expressed by a finite complement clause. The first two categories in the hierarchy are irrelevant for this prediction, as they can only be expressed by noun phrases.

As shown in the previous section, not all perception verbs allow all semantic complement types. In order to test the prediction in (52) we therefore have to limit ourselves to the perception verbs that allow a wide range of semantic complement types. The ones we have selected are those that allow at least an Episode as their semantic complement. Table 4 shows which perception verbs comply with this criterion. The data on which this table and later tables in this section are based are all given in Appendix 2.

\begin{tabular}{|c|c|c|c|c|c|}
\hline & Property & Individual & State-of-Affairs & Episode & Communicated content \\
\hline Escutar & + & + & + & + & + \\
\hline Ouvir & + & + & + & + & + \\
\hline Ver & + & + & + & + & + \\
\hline Avistar & + & + & + & + & \\
\hline Notar & + & + & + & + & \\
\hline Observar & + & + & + & + & \\
\hline Perceber & + & + & + & + & \\
\hline Sentir & + & + & + & + & \\
\hline Visualizar & + & + & + & + & \\
\hline
\end{tabular}

Table 4. Perception verbs exhibiting a wide range of semantic complement types 
Table 5 now shows the ways in which the complement types expressing States-of-Affairs, Episodes, and Communicated Contents are realized morphosyntactically in terms of finiteness. In this table a + indicates that a complement is finite, a - that it is non-finite, while 'irr' indicates that a slot is irrelevant.

Table 5. Finiteness of complements

\begin{tabular}{llll}
\hline & State-of-Affairs & Episode & Communicated content \\
\hline Escutar & - & $-/+$ & $-/+$ \\
Ouvir & - & $-/+$ & $-/+$ \\
Ver & - & $-/+$ & $-/+$ \\
Avistar & - & $-/+$ & irr \\
Notar & - & $-/+$ & irr \\
Observar & - & $-/+$ & irr \\
Perceber & - & $-/+$ & irr \\
Sentir & - & $-/+$ & irr \\
Visualizar & - & $-/+$ & irr \\
\hline
\end{tabular}

What is clear from Table 5 is that there is a clear split between complements designating States-of-Affairs on the one hand, and those designating Episodes and Communicated Contents on the other. The former are always expressed through non-finite forms, the latter through finite and non-finite forms.

A further generalization arises when we further distinguish between the two non-finite forms, progressive and infinitival forms, and consider their distribution across semantic complement types. This is shown in Table 6.

Table 6. Progressive, infinitival, and finite complements

\begin{tabular}{llll}
\hline & State-of-Affairs & Episode & Communicated content \\
\hline Escutar & PROG/INF & INF/FIN & INF/FIN \\
Ouvir & PROG/INF & INF/FIN & INF/FIN \\
Ver & PROG/INF & INF/FIN & INF/FIN \\
Avistar & PROG/INF & INF/FIN & irr \\
Notar & PROG/INF & INF/FIN & irr \\
Observar & PROG/INF & INF/FIN & irr \\
Perceber & PROG/INF & INF/FIN & irr \\
Sentir & PROG/INF & INF/FIN & irr \\
Visualizar & PROG/INF & INF/FIN & irr \\
\hline
\end{tabular}

Table 6 shows that progressive forms are only found in the expression of complements designating Statesof-Affairs. A construction with an ep- or C-complement in the progressive form is ungrammatical, as shown in (53), or results in a State-of-Affairs reading, as in (54):

\begin{tabular}{|c|c|c|c|c|}
\hline $\begin{array}{l}\text { Porém, } \\
\text { however }\end{array}$ & $\begin{array}{l}\text { notamos } \\
\text { note.PRES.1PL }\end{array}$ & $\begin{array}{l}\text { ser } /{ }^{\star} \text { sendo } \\
\text { COP.INF/COP.PROG }\end{array}$ & $\begin{array}{l}\text { comum } \\
\text { common }\end{array}$ & \\
\hline cerne & dessas & teorias & idéia & igualdade. \\
\hline
\end{tabular}

'However, we note that the idea of equality is common to the core of those theories.'

\begin{tabular}{|c|c|c|c|c|c|c|c|}
\hline \multirow{2}{*}{$\begin{array}{l}\text { Durante a } \\
\text { during the } \\
\text { ouvi }\end{array}$} & \multicolumn{2}{|c|}{$\begin{array}{l}\text { transmissão } \\
\text { broadcast }\end{array}$} & \multirow{2}{*}{$\begin{array}{l}\text { do } \\
\text { of.the } \\
\text { Fla }\end{array}$} & \multirow{2}{*}{$\begin{array}{l}\text { jogo } \\
\text { game } \\
\text { tá }\end{array}$} & $\begin{array}{l}\text { São Paulo } \\
\text { São Paulo }\end{array}$ & \multirow[t]{2}{*}{$\begin{array}{l}\mathrm{x} \\
\text { versus }\end{array}$} & \multirow[t]{2}{*}{$\begin{array}{l}\text { Boca Juniors } \\
\text { Boca Juniors }\end{array}$} \\
\hline & que & 0 & & & & & \\
\hline hear.PST.1sG & that & the & Fla & COP.PRS & $.3 \mathrm{SG}$ & te.PROG & \\
\hline com & Alex & Dias & para & 0 & ano & vem/ & \\
\hline with & Alex & Dias & for & the & year & come.I & SS.3SG \\
\hline
\end{tabular}




o Fla negociando com o Alex Dias para o ano que vem.
the Fla negotiate.PROG with the Alex Dias for the year that come.PRs.3SG
'During the broadcast of the game between São Paulo and Boca Juniors I heard that Fla is
negotiating with Alex Dias for next year/Fla negotiating with Alex Dias for next year.'

Together with the data in Table 5, this leads to the overall picture presented in Table 7.

Table 7. Semantic and morphosyntactic types of complement clause

\begin{tabular}{llll}
\hline & State-of-Affairs & Episode & Communicated Content \\
\hline progressive & + & & \\
infinitive & + & + & + \\
finite & & + & + \\
\hline
\end{tabular}

In all, and as predicted, we thus see a clear relationship between the semantic complement types on the one hand, and their morphosyntactic expression on the other. ${ }^{11}$

\section{Conclusions}

In this paper we have shown that the complements of perception verbs in Brazilian Portuguese can be classified semantically using the semantic and pragmatic categories proposed in Functional Discourse Grammar. Complements of perception verbs can be argued to express Properties (f), Individuals (x), Statesof-Affairs (e), Episodes (ep), and Communicated Contents (C). This subdivision into complement types is relevant in two different respects. First of all, the set of semantic complement types that a perception verb can take is not random but follows a hierarchy, in which the categories mentioned above are ranked from lower to higher scope. If a perception verb can take a semantic complement type of a certain scope, it can also take all other semantic complement types with lower scope. And secondly, the morphosyntactic expression of complements of perception verbs in Brazilian Portuguese is closely linked to their semantic types: the higher a complement in the semantic hierarchy, the more likely it is to be expressed by finite forms. We furthermore found that progressive forms are limited to complements denoting States-of-Affairs. In all, this study thus has shown that the semantic categories of complements distinguished in FDG provide a useful categorization that helps to systematically describe the semantic and morphosyntactic behaviour of perception verbs in their many readings as well as their complements in their many formal manifestations.

Acknowledgements: We are very grateful to three anonymous reviewers for their helpful comments on an earlier version of this paper.

\section{References}

Aikhenvald, Alexandra Y., Anne Storch. 2013. Linguistic expression of perception and cognition. In Aikhenvald, Alexandra Y., Anne Storch (eds.), Perception and cognition in language and culture. Leiden: Brill, 1-45.

Barros, Anna Rachel Machado. 1977. Aspectos da complementação de uma classe de verbos de percepção. MA thesis, Instituto de Estudos Linguísticos, Universidade Estadual de Campinas.

Barwise, Jon, John Perry. 1983. Situations and attitudes. Cambridge, Mass.: The MIT Press.

Bastos, Sandra D. G., Vânia C. C. Galvão, Sebastião C. L. Gonçalves, Marize M. D. Hattnher, Kees Hengeveld, Gisele C. de Sousa, Valéria Vendrame. 2007. The expressibility of modality in representational complement clauses in Brazilian

11 This is all the more interesting, as similar results were obtained for noun complements in Brazilian Portuguese in Souza (2016). 
Portuguese. In Hattnher, Marize M.D., Kees Hengeveld (eds.), Advances in Functional Discourse Grammar (Alfa - Revista de Lingüística 51.2, special issue), 189-212.

Carvalho, Cristina dos Santos. 2004. Cláusulas encaixadas em verbos causativos e perceptivos: uma análise funcionalista. $\mathrm{PhD}$ thesis Instituto de Estudos Linguísticos, Universidade Estadual de Campinas.

Dik, Simon C., Kees Hengeveld. 1991. The hierarchical structure of the clause and the typology of perception verb complements. Linguistics 29.2, 231-259.

Gisborne, Nikolas. 2010. The event structure of perception verbs. Oxford: Oxford University Press.

Hengeveld, Kees. 1998. Adverbial clauses in the languages of Europe. In Johan van der Auwera (ed.), Adverbial constructions in the languages of Europe. Berlin: Mouton de Gruyter, 335-419.

Hengeveld, Kees, Marize Mattos Dall'Aglio Hattnher. 2015. Four types of evidentiality in the native languages of Brazil. Linguistics 53.3, 479-524.

Hengeveld, Kees, J. Lachlan Mackenzie. 2008. Functional Discourse Grammar: A typologically-based theory of language structure. Oxford: Oxford University Press.

Hengeveld, Kees, J. Lachlan Mackenzie. 2010. Functional Discourse Grammar. In Heine, Bernd, Heiko Narrog (eds.), The Oxford Handbook of Linguistic Analysis. Oxford: Oxford University Press, 367-400.

Hengeveld, Kees, Gerry Wanders. 2007. Adverbial conjunctions in Functional Discourse Grammar. In Mike Hannay, Steen, Gerard (eds.), Structural-functional studies in English grammar: In honor of Lachlan Mackenzie. Amsterdam: Benjamins, 211-227.

Holierhoek, Christina Margaretha Geertruida. 1980. Werkwoorden van waarneming. PhD thesis. University of Leiden.

Keizer, Evelien. 2015. A functional discourse grammar for English. Oxford: Oxford University Press.

Kirsner, Robert S., Sandra A. Thompson. 1976. The role of pragmatic inference in semantics: a study of sensory verb complements in English. Glossa 10, 200-240.

Noonan, Michael. 1985. Complementation. In Shopen, Timothy (ed.), Language typology and syntactic description, Vol.II. Cambridge: Cambridge University Press, 42-140.

Souza, Edson Rosa Francisco de. 2016. A oração completiva nominal. In Pezatti, Erotilde Goreti (ed.), Construções subordinadas na lusofonia. São Paulo: Editora da UNESP.

van der Auwera, Johan. 1985. The predicative relatives of French perception verbs. In Bolkestein, A. Machtelt, Casper de Groot, J. Lachlan Mackenzie (eds.), Predicates and terms in Functional Grammar. Dordrecht: Foris, 219-234.

Vendrame, Valéria (2010), Os verbos ver, ouvir e sentir e a expressão de evidencialidade em língua portuguesa. PhD thesis, Instituto de Biociências, Letras e Ciências Exatas da Universidade Estadual Paulista, Campus de São José do Rio Preto.

Viberg, Åke. 1984. The verbs of perception: a typological study. Linguistics 21.1, 123-162. 


\section{Appendix 1: Semantic complement types with Brazilian Por- tuguese perception verbs}

\section{Visual perception - Property}

Avistar

$\begin{array}{lllllll}\text { Chegando } & \text { em Itu, } & \text { num } & \text { belo } & \text { sítio } & & \\ \text { arriving.PRoG } & \text { in In } & \text { in.a } & \text { beautiful } & \text { farm } & & \\ \text { das árvores } & \text { pintadas } & \text { de } & \text { branco na } & \text { base, meias socket, } \\ \text { of.the trees } & \text { painted } & \text { of } & \text { white in.the base, socks ankle } \\ \text { avistei } & \text { o azul } & \text { da } & \text { piscina. } & & & \\ \text { see.PST.1sG } & \text { the blue } & \text { of.the } & \text { swimming.pool }\end{array}$

'Arriving at Itu, in a beautiful farm with trees painted in white at the base, ankle socks, I saw the blue of the swimming pool.'

Notar

Eles já notaram a cor do biquini?

3PL already note.PST.3PL the color of.the bikini

É de encher os olhos: azul e branco.

COP.PRS.3SG of fill.INF the eyes blue and white

'Have they already noted the color of the bikini? It is a sight to see: blue and white.

\section{Observar}

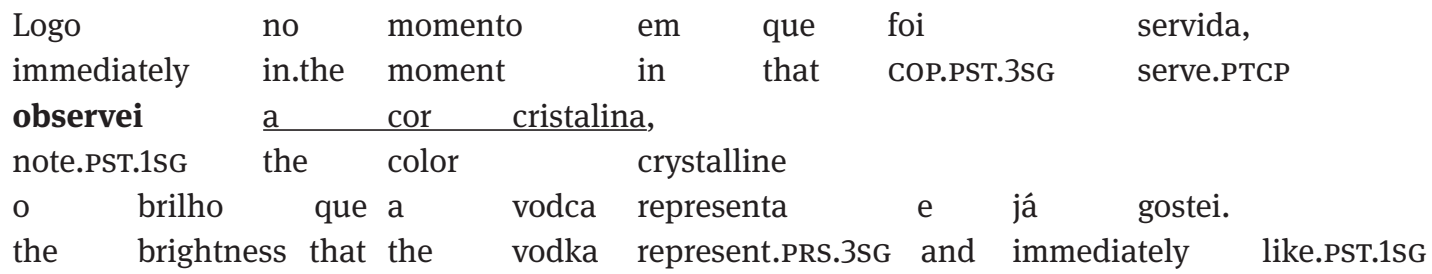

'As soon as the drink was served, I noticed the crystalline color, the brightness that vodka represents and I liked it immediately.'

Olhar

Olhei

look.PST.1SG

$\begin{array}{llll}\text { a } & \text { cor } & \text { daquel } & \text { flor. } \\ \text { the } & \text { color } & \text { of.that } & \text { flower }\end{array}$

'I looked at the color of that flower. 
Perceber

\begin{tabular}{|c|c|c|c|c|c|c|c|c|}
\hline $\begin{array}{l}\text { Muitas } \\
\text { many }\end{array}$ & $\begin{array}{l}\text { vezes } \\
\text { times }\end{array}$ & $\begin{array}{l}\text { emgolem } \\
\text { swallow.PRS.3PL }\end{array}$ & $\begin{array}{l}\text { a } \\
\text { the }\end{array}$ & $\begin{array}{l}\text { comida } \\
\text { food }\end{array}$ & & & & \\
\hline $\begin{array}{l}\text { sem } \\
\text { without }\end{array}$ & $\begin{array}{l}\text { sequer } \\
\text { even }\end{array}$ & $\begin{array}{l}\text { parar para } \\
\text { stop.INF to }\end{array}$ & $\begin{array}{l}\text { sentir } \\
\text { feel.INF }\end{array}$ & $\begin{array}{l}\mathrm{o} \\
\text { the }\end{array}$ & $\begin{array}{l}\text { sabor, } \\
\text { flavor, }\end{array}$ & $\begin{array}{l}\text { perceber } \\
\text { perceive.INF }\end{array}$ & the & $\begin{array}{l}\text { cor. } \\
\text { color }\end{array}$ \\
\hline
\end{tabular}

Ver

Senti o teu cheiro perto de mim, o calor do teu corpo,

feel.PST.1sG the 2sG.POSs scent close of 1SG.oBL the heat of.the 2sG.Poss body

vi $\quad \underline{0}$ verde dos teus olhos, mais brilhantes do que nunca.

see.PST.1SG the green of.the 2SG.POSS eyes more shiny of.the that never

'I felt your scent close to me, the heat of your body, I saw the green of your eyes, shinier than ever.'

Visualizar

$\begin{aligned} & \text { Informe à } \\ & \text { inform.IMP gráfica }\end{aligned}$ to.the printing.house in $\begin{aligned} & \text { em qual escala você } \\ & \text { a visualizou } \\ & \text { a cor. }\end{aligned}$
the color
'Inform the printing house in which scale you visualized the color.'

\section{Visual perception - Individual}

Avistar

Antes que eu respondesse

before that 1SG answer.PST.SBJV.1SG

avistei $\quad \underline{0 \quad \text { cavalo }}$ um pouco mais para baixo.

see.PST.1SG the horse a little more for down

'Before I answered I saw the horse a little more downward.'

Notar

Então, provavelmente, vocês notaram $\quad \underline{0}$ cachorro.

then probably 2PL notice.PST.2PL the dog

'And then, probably, you noticed the dog.'

Observar

Eles apenas observaram os animais, nada de tiros.

3PL only observe.PST.3PL the animals nothing of shots

'They only observed the animals, there were no shots.' 
Olhar

$\begin{array}{llllll}\text { Olhei } & \text { o } & \text { homem } & \text { à } & \text { minha } & \text { esquerda. } \\ \text { look.PST.1SG } & \text { the } & \text { man } & \text { at.the } & \text { 1SG.POSS } & \text { left }\end{array}$

'I looked at the man on my left.

\section{Perceber}

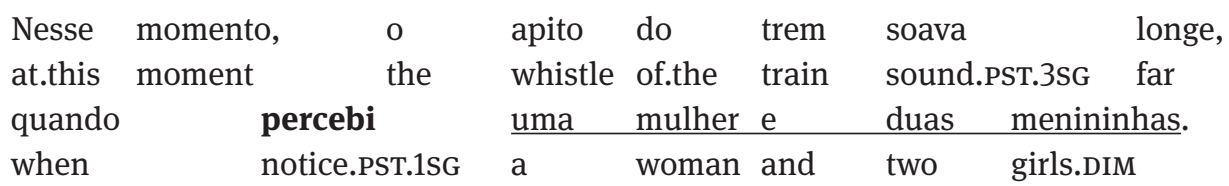

'At this moment the train whistle sounded at a distance, when I noticed a woman and two little girls.'

Ver

Você viu aquela mulher da novela?

2SG see.PST.2SG that woman of.the soap.opera

'Did you see that woman from the soap opera?

\section{Visualizar}

Pensativo, o dono do (ex-)castelo visualizou seu pai. thoughtful the owner of.the (ex-)castle visualize.PST.3Sg 3sG.Poss father 'Thoughtful, the owner of the (ex-)castle visualized his father.'

\section{Visual perception - State-of-Affairs}

Avistar

\begin{tabular}{|c|c|c|c|c|c|c|}
\hline Avistei & ele & vindo & na & minha & direção todo & lindo, \\
\hline see.PS & $3 \mathrm{~s}$ & ve.PROG & in.the & my & direction & adsome \\
\hline $\begin{array}{l}\text { vestindo } \\
\text { wear.PROG }\end{array}$ & $\begin{array}{l}\text { uma } \\
\text { a }\end{array}$ & $\begin{array}{ll}\text { camisa } & \text { branca, } \\
\text { shirt } & \text { white }\end{array}$ & $\begin{array}{l}\text { jaqueta } \\
\text { jacket }\end{array}$ & $\begin{array}{l}\text { azul } \\
\text { blue }\end{array}$ & $\begin{array}{l}\text { calça } \\
\text { trouser }\end{array}$ & $\begin{array}{l}\text { jeans. } \\
\text { jeans }\end{array}$ \\
\hline
\end{tabular}

'I saw him moving toward me looking all handsome, in a white shirt, blue jacket and jeans.'

Notar

Nem notaram $\underline{0}$ homem de paletó preto entrar apressado na sala. not note.PST.3PL the man of jacquet black enter.INF quickly in.the room 'They didn't even notice the man in a black jacquet entering quickly in the room.' 
Observar

$\begin{array}{llllllll}\text { Eu } & \text { observei } & \text { eles } & \text { dormindo } & \text { por } & \text { mais } & \text { um } & \text { tempo } \\ \text { 1SG } & \text { watch.PST.1SG } & \text { 3PL } & \text { sleep.PROG } & \text { for } & \text { more } & \text { a } & \text { time } \\ \text { e } & \text { fui } & \text { pra } & \text { casa. } & & & & \\ \text { and } & \text { go.PST.1SG } & \text { for } & \text { home } & & & & \end{array}$

'I watched them sleeping for another while and then went home.'

Olhar

$\begin{array}{lllllllll}\text { Olhei } & \text { o } & \text { homem } & \text { louco tocando } & \text { os } & \text { sinos da } & \text { igreja } \\ \text { look.PST.1sG } & \text { the } & \text { man } & \text { crazy } & \text { ring.PROG } & \text { the } & \text { bells of.the church } \\ \text { por quase } & \text { uma } & \text { hora. } & & & & & & \\ \text { for almost an } & \text { hour } & & & & & \end{array}$

'I looked at the crazy man ringing the church bells for almost an hour.'

Perceber

$\mathrm{Eu}$ percebi eles fazendo força pra arrancar algo.

1SG notice.PST.1SG 3PL do.PROG force to pull.out.INF something

'I noticed them striving to pull something out.'

Ver

\begin{tabular}{|c|c|c|c|c|c|c|}
\hline $\mathrm{Eu}$ & e & um & amigo & vimos & & \\
\hline $\begin{array}{l}1 S G \\
\text { ele }\end{array}$ & $\begin{array}{l}\text { and } \\
\text { dando }\end{array}$ & $\mathrm{a}$ & $\begin{array}{l}\text { friend } \\
\text { um }\end{array}$ & $\begin{array}{l}\text { see.PST.1PL } \\
\text { empurrãozinho }\end{array}$ & no & antebraco. \\
\hline & give. & & $\mathrm{a}$ & push.DIM & in.the & forearm \\
\hline
\end{tabular}

'A friend and I saw him giving a little push on his forearm.'

Visualizar

$\begin{array}{llllllll}\text { Uma } & \text { vez } & \text { visualizei } & \text { Deus } & \text { pairando } & \text { sobre } & \text { a } & \text { Terra. } \\ \text { one } & \text { time } & \text { visualize.PST.1SG God } & \text { hover.PROG } & \text { over } & \text { the } & \text { Earth }\end{array}$

'Once I visualized God hovering over the Earth.'

Visual perception - Episode

Avistar

Por um golpe de sorte,

by a stroke of luck

avistei que um dos carros

notice.PST.1sG that one of.the cars

estava deixando 0 "estacionamento oficial” da instituição

COP.PST.3SG leave.PROG the parking.lot official of.the institution 


\begin{tabular}{|c|c|c|c|}
\hline ROG & $\begin{array}{l}\text { assim, } \\
\text { thus }\end{array}$ & $\begin{array}{l}\mathrm{a} \\
\text { the }\end{array}$ & $\begin{array}{l}\text { minha } \\
\text { 1sG.Poss }\end{array}$ \\
\hline
\end{tabular}

'By a lucky fluke, I noticed that one of the cars was leaving the institution's official parking lot, thus opening up my much-desired parking space.'

Notar

$\begin{array}{llllll}\text { Notamos } & \text { ser } & \text { a } & \text { espiritualidade } & & \\ \text { note.PRES.1PL } & \text { COP.INF } & \text { the } & \text { spirituality } & & \\ \text { algo } & \text { de } & \text { suma } & \text { importância } & \text { para } & \text { você. } \\ \text { something } & \text { of } & \text { great } & \text { importance } & \text { for } & \text { 2sG }\end{array}$

'We note that spirituality is something of great importance to you.'

\subsubsection{Observar}

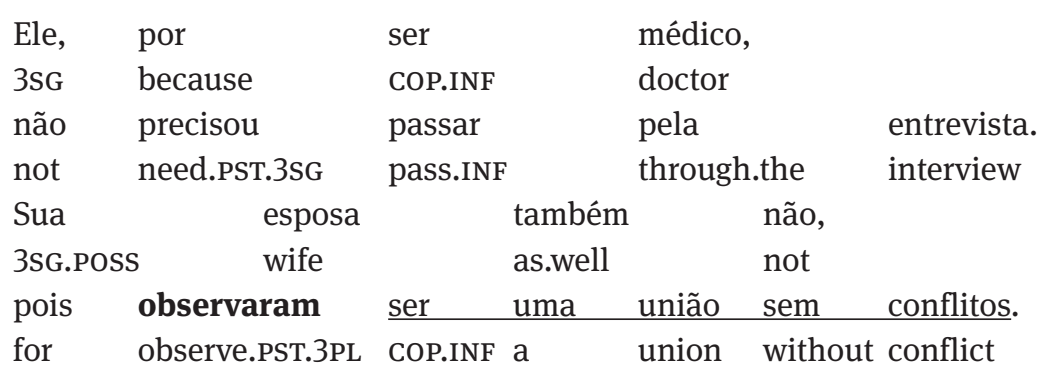

'Because he is a doctor, he did not have to be interviewed. His wife did not either, for they observed it to be a union without conflict.'

Perceber

$\begin{array}{llllllll}\text { Percebo } & \text { que } & \text { o } & \text { mundo } & \text { está } & \text { cansado } & \text { de } & \text { sonhadores! } \\ \text { perceive.PRS.1sG that } & \text { the } & \text { world } & \text { COP.PRS.3SG } & \text { tired } & \text { of } & \text { dreamers }\end{array}$

'I notice that the world is tired of dreamers!'

Ver

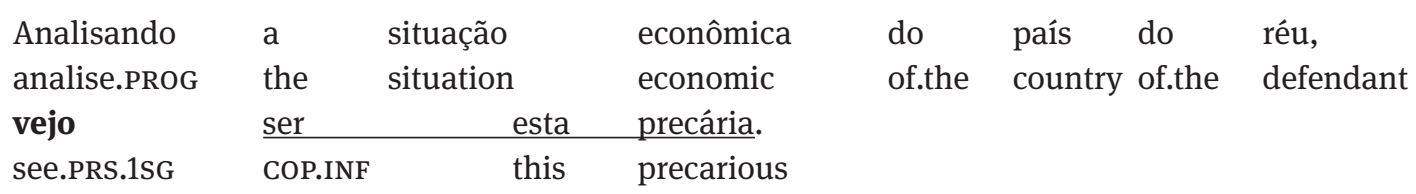

'Analyzing the economic situation of the defendant's country, I see it is precarious.'

\section{Visualizar}

$\begin{array}{llllll}\text { O presidente } & \text { da } & \text { Funai, } & \text { Mércio Pereira } & \text { Gomes, } & \\ \text { the presidente } & \text { of.the } & \text { Funai } & \begin{array}{l}\text { Mércio Pereira } \\ \text { possivel }\end{array} & \begin{array}{l}\text { Gomes } \\ \text { fazer }\end{array} & \text { valer } \\ \text { visualizou } & \text { ser } & & \text { pesisele } & \text { do.INF } & \text { assert.INF } \\ \text { visualize.PST.3SG } & \text { COP.INF } & \text { possible } & & & \end{array}$




\begin{tabular}{|c|c|c|c|c|c|}
\hline os & direitos & & das & etnias & indígenas \\
\hline the & rights & & of.the & ethnic.groups & indigenous \\
\hline para & 0 & acesso & $\mathrm{ao}$ & ensino & diferenciado. \\
\hline
\end{tabular}

'The president of Funai, Mércio Pereira Gomes, visualized that it is possible to assert the rights of indigenous ethnic groups to access differentiated instruction.

\section{Visual perception - Communicated Content}

Ver

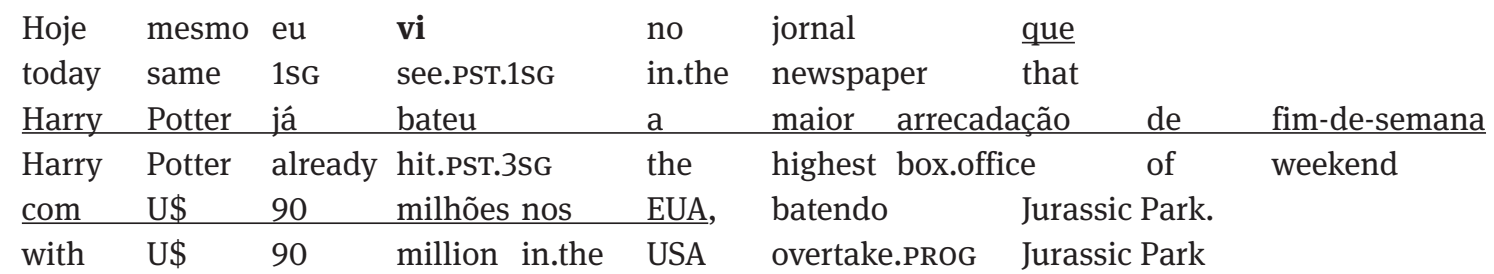

'Right today I saw in the newspaper that Harry Potter has already hit the highest weekend box office with $\$$ 90 million in the USA, overtaking Jurassic Park.'

\section{Auditory perception - Property}

Escutar

$\mathrm{Eu}$ escuto sons.

1SG hear.PRs.1SG sounds

'I hear sounds.'

Notar

Assim que notei o barulho, com $500 \mathrm{~km}$, levei $\quad$ o carro as.soon that note.PST.1SG thenoise with $500 \mathrm{~km}$ took.PST.1sG the car na concessionária.

to.the dealer

'As soon as I noticed the noise, after $500 \mathrm{~km}$, I took the car to the dealer.'

Observar

\begin{tabular}{lllllll} 
Observei & um & barulho & na & \multicolumn{2}{c}{ transmissão } \\
notice.PST.1sG & a & noise & in.the & \multicolumn{2}{c}{ transmission } & \\
de $\quad$ marchas & $2^{\underline{a}}$ & para & $3^{\text {a }}$ & em & baixa & aceleração. \\
from $\quad$ gears & $2^{\text {nd }}$ & to & $3^{\text {rd }}$ & in & low acceleration
\end{tabular}

'I noticed a noise in the transmission from 2nd to 3rd gears in low acceleration.' 
Ouvir

$\begin{array}{lllll}\text { Ouvi } & \underline{0} & \text { barulho } & \text { da } & \text { chuva. } \\ \text { hear.PST.1sG } & \text { the } & \text { noise } & \text { of.the } & \text { rain }\end{array}$

'I heard the noise of the rain.'

\section{Perceber}

$\begin{array}{llllllll}\text { Comprei } & \text { um } & \text { cabo } & \text { Stinger Hyperserie } & \text { e } & \text { após a } & \text { instalação } \\ \text { buy.PST.1sG } & \text { a } & \text { cabe } & \text { Stinger Hyperserie } & \text { and } & \text { after } & \text { the } & \text { installation } \\ \text { percebi } & \text { os } & \text { ruídos } & \text { quando ligava o } & \text { motor } & \text { [do } & \text { carro] } & \\ \text { notice.PST.1SG } & \text { the } & \text { noises } & \text { when turn on.PST.1sG } & \text { the } & \text { engine } & \text { [of.the car] }\end{array}$

'I bought a Stinger Hyperserie cable and after the installation I noticed the noises when I turned on the engine.'

Ver

Vi um barulho de carro. Seria a estrada?

hear.PST.1SG a noise of car COP.COND.3sg the road

'I heard the noise of a car. Would it be the road?'

\section{Auditory perception - Individual}

Escutar

E eu escutei $\quad \underline{0}$ passarinho.

and 1SG hear.PST.1SG the little.bird

'And I heard the little bird.'

Ouvir

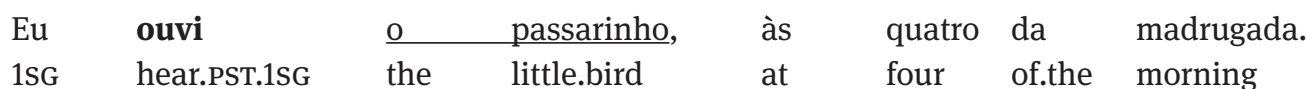

'I heard the little bird at four in the morning.'

\section{Auditory perception - State-of-Affairs}

\section{Escutar}

\begin{tabular}{|c|c|c|c|c|}
\hline Escutávamos & galera & gritando & "Ronaldinho" & direto. \\
\hline hear.PST.1PL & crowd & shout.PROG & "Ronaldinho" & constantly \\
\hline
\end{tabular}


Ouvir

\begin{tabular}{llllllllll} 
Eu & ouvi & & o & Diu & dizendo & que & 0 & serviço \\
1SG & hear.PST.1SG & the & Diu & \multicolumn{2}{l}{ say.PROG } & that the & service & \\
vai & ser & feito & & lá & pelo & pessoal & do & Rio. \\
go.PRES.3SG & COP.INF & do.PTCP & & there by.the & people & from.the Rio
\end{tabular}

'I heard Diu saying that the service will be done by the people from Rio.'

\section{Auditory perception - Episode}

Escutar

\begin{tabular}{|c|c|c|c|c|c|}
\hline $\begin{array}{l}\text { Tô } \\
\text { COP.PRS.1SG }\end{array}$ & $\begin{array}{l}\text { dançando } \\
\text { dance.PROG }\end{array}$ & $\begin{array}{ll}\text { na } & \text { balada } \\
\text { in.the } & \text { party }\end{array}$ & $\begin{array}{l}\mathrm{e} \\
\text { and }\end{array}$ & & \\
\hline escuto & que & próxima & música é uma que & $\mathrm{eu}$ & amo. \\
\hline lear.PRS.1SG & that the & next & song is one that & $1 \mathrm{SG}$ & love.PRS.1sG \\
\hline
\end{tabular}

Ouvir

\begin{tabular}{|c|c|c|c|c|c|}
\hline $\begin{array}{l}\text { Quando } \\
\text { when }\end{array}$ & $\begin{array}{l}\text { pego } \\
\text { take.PRS.1SG }\end{array}$ & $\begin{array}{l}\text { o } \\
\text { the }\end{array}$ & $\begin{array}{l}\text { telefone } \\
\text { phone } \\
\text { não }\end{array}$ & entra & $\begin{array}{l}\text { ouço } \\
\text { hear.PRS.1SG } \\
\text { na }\end{array}$ \\
\hline que & $\begin{array}{ll}\mathrm{O} & \text { modem } \\
\text { the } & \text { modem }\end{array}$ & & nao & emild & $\begin{array}{l}\text { na } \\
\text { in }\end{array}$ \\
\hline
\end{tabular}

'When I take the phone, I hear the modem doesn't connect.'

\section{Auditory perception - Communicated Content}

Escutar

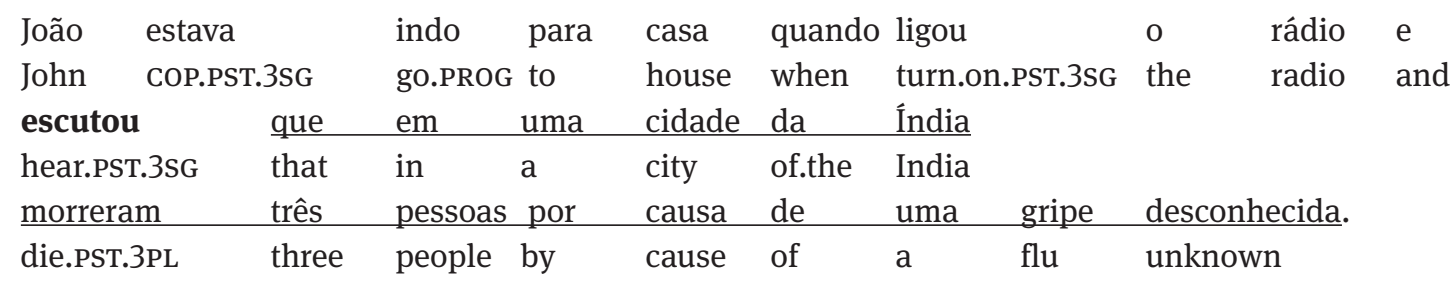

'John was going home when he turned on the radio and heard that in a city in India three people died of an unknown flu.'

Ouvir

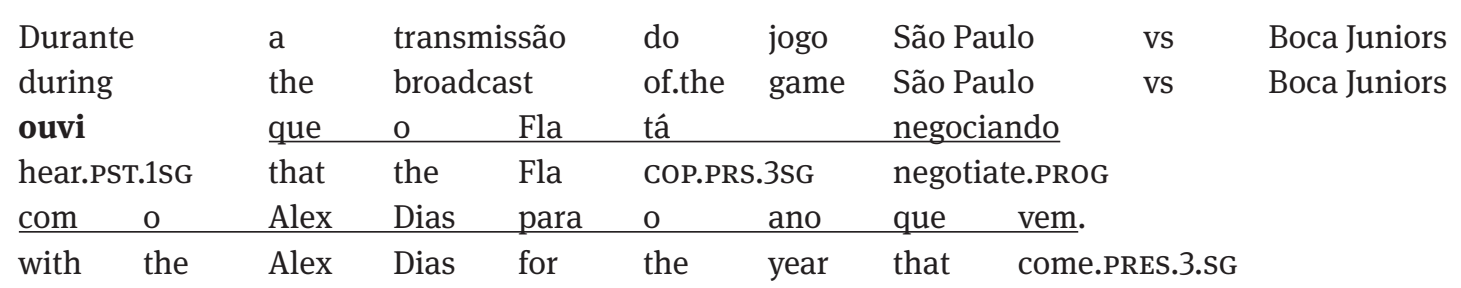


'During the transmission of the match São Paulo vs. Boca Juniors I heard that Fla(mengo) is negotiating with Alex Dias for next year.'

\section{Olfactory perception - Property}

Cheirar

Cheirei

smell.PST.1SG

$\underline{0} \quad$ perfume

de seus cabelos.

'I smelled the perfume of her hair.'

\section{Experimentar}

$\begin{array}{llllllll}\mathrm{Na} & \text { verdade ainda } & \text { estou } & \text { em } & \text { duvida, } & & \\ \text { in.the } & \text { truth still } & \text { COP.PRS.1SG } & \text { in } & \text { doubt } & & \\ \text { eu } & \text { experimentei } & \text { umas } & \text { três } & \text { ou } & \text { quatro fragrâncias } & \text { nos braços. } \\ \text { 1SG } & \text { try.PST.1SG } & \text { some three } & \text { or } & \text { four fragrances } & \text { in.the arms }\end{array}$

'In fact I'm still in doubt, I have tried three or four fragrances on my arms.'

Perceber

$\begin{array}{lllllll}\text { Ontem } & \text { percebi } & \underline{a} & \text { suavidade } & \text { do } & \text { teu } & \text { perfume. } \\ \text { yesterday } & \text { perceive.PST.1sG } & \text { the } & \text { softness } & \text { of.the } & \text { 2sG.POSS } & \text { perfume }\end{array}$

'Yesterday I perceived the softness of your perfume.'

Sentir

$\begin{array}{lllll}\mathrm{Eu} & \text { senti } & \text { cheiro } & \text { de } & \text { marmelo. } \\ \text { 1SG } & \text { feel.PST.1SG } & \text { smell } & \text { of } & \text { quince }\end{array}$

'I felt the smell of quince.'

\section{Olfactory perception - Individual}

\section{Cheirar}

Cheirei

$$
\begin{array}{ll}
\text { aquele homem de } \\
\text { that man of }
\end{array}
$$

smell.PST.1SG

tão lindo,

such handsome

tão especial.

'I smelled that handsome special man.'

\section{Experimentar}

$\begin{array}{lllllllll}\text { Experimentei } & \text { o } & \text { perfume, } & \text { que é } & \text { do meu namorado, } & \\ \text { try.PST.1SG } & \text { the } & \text { perfume } & \text { which } & \text { is } & \text { of.the my } & \text { boyfriend } & \\ \text { e } \quad \text { fiquei } & & \text { encantada } & \text { com } & \text { a } & \text { fixação e } & \text { com o } & \text { cheiro. } \\ \text { and stay.PST.1SG } & \text { delighted } & \text { by } & \text { the } & \text { fixation and by the } & \text { smell }\end{array}$

'I tried the perfume, which is my boyfriend's, and I was delighted by the fixation and the smell.' 
Perceber

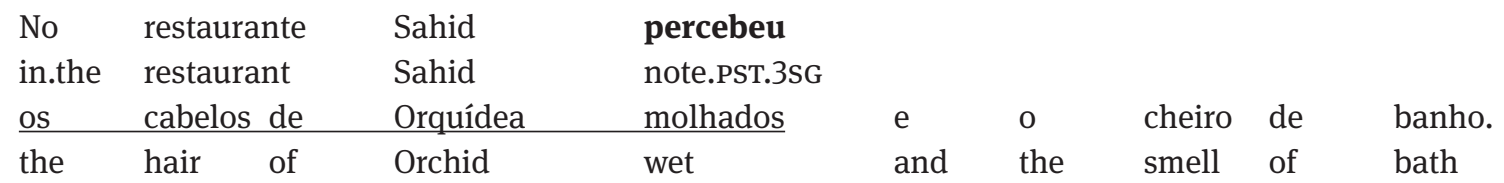

'In the restaurant Sahid noticed Orquidea's wet hair and the smell of bath.'

Sentir

Senti aquele corpo perfumado sobre o meu,

feel.PST.1SG that body perfumed over the 1sG.Poss

aqueles cabelos longos sedosos roçando o meu rosto.

that hair long silky brush.PROG the 1sG.Possface

'I felt that perfumed body over mine, that silky long hair brushing my face.

\section{Olfactory perception - State-of-Affairs}

Perceber

$\begin{array}{lllll}\text { Não } & \text { percebi } & \text { o } & \text { bolo } & \text { queimando. } \\ \text { not } & \text { note.PST.1SG } & \text { the } & \text { cake } & \text { burn.PROG }\end{array}$

'I did not notice the cake was burning.'

Sentir

Continuamos o passeio como antigamente,

continue.PRS.1PL the walk like in.the.old.days

$\begin{array}{lllllll}\text { sentindo } & \text { o } & \text { pó } & \text { levantar-se } & \text { a } & \text { cada } & \text { passada, } \\ \text { feel.PROG } & \text { the } & \text { dust } & \text { rise.INF-REFL } & \text { at } & \text { each } & \text { step }\end{array}$

pois a chuva este ano tarda.

because the rain this year be.late.3sG

'We continue the stroll as in the old days, feeling the dust rising at each step, because this year the rain is late.'

\section{Olfactory perception - Episode}

Perceber

$\begin{array}{llllll}\text { Logo percebi } & \text { que } & \text { a } & \text { rosca } & \text { estava } & \text { queimando, } \\ \text { soon } & \text { realize.PST.1SG that } & \text { the doughnut } & \text { COP.PST.3SG } & \text { burn.PROG } \\ \text { mas o padeiro nem } & \text { reparou. } & \\ \text { but the baker not } & \text { notice.PST.3SG } & \\ \text { 'I soon realized that the doughnut was burning, but the baker did not notice.' }\end{array}$


Sentir

$\begin{array}{llllll}\text { Senti } & \text { que } & \text { o } & \text { feijão } & \text { estava } & \text { queimando. } \\ \text { feel.PST.1SG } & \text { that } & \text { the } & \text { beans } & \text { coP.PST.3SG } & \text { burn.PROG }\end{array}$

'I noticed that the beans were burning.'

\section{Gustatory perception - Property}

$\begin{array}{llll}\begin{array}{l}\text { Degustar } \\ \text { Pedalei }\end{array} & \text { junto com vocês } \mathrm{e} & \\ \text { cycle.PST.1SG } & \text { together with 2.PL and } & \\ \text { degustei } & \text { as delícias } & \text { da comida espanhola. } \\ \text { taste.PST.1SG } & \text { the delights } & \text { of.the food Spanish } \\ \text { 'I cycled with you and tasted the joys of Spanish food.' }\end{array}$

'I cycled with you and tasted the joys of Spanish food.'

\section{Experimentar}

$\begin{array}{llllllll}\text { Já } & \text { experimentamos } & \text { o } & \text { sabor romã com } & \text { chocolate, } \\ \text { already } & \text { taste.PST.1PL } & \text { the } & \text { flavor } & \text { pomegranate and } & \text { chocolate } \\ \text { que } & \text { foi } & \text { aprovadíssimo } & \text { por todos. } & \\ \text { which } & \text { go.PST.3SG } & \text { approved.AUGM } & \text { by } & \text { everyone }\end{array}$

'We have already tasted the pomegranate and chocolate flavor, which everyone very much liked.'

Perceber

Quando dei o primeirogole percebi

when give.PST.1SG the first sip notice.PST.1sG

um gosto meio esquisito mas continuei bebendo até 0 final.

a taste half strange but keep.PST.1SG drink.PRog until the end

'When I took the first sip I noticed a strange taste but I kept on drinking until I finished.'

Provar

Com nossos sentidos, provamos sabores.

with 1PL.Poss senses taste.PRES.1PL flavors

'Using our senses, we taste flavors.'

\section{Saborear}

Já saborearam o sabor adocicado do caju?

already taste.PST.3PL the flavor sweet of.the cashew

'Have you already tasted the sweet flavor of the cashew nuts?' 
Sentir

Hoje nem senti $\underline{0}$ gosto da comida direito.

today not taste.PST.1SG the flavor of.the food well

'Today I haven't tasted the food's flavor very well.'

\section{Gustatory perception - Individual}

Degustar

Presidente Lula degusta frango

President Lula eat.PRS.3SG chicken

após lançamento do Plano de Prevenção da Influenza Aviária.

after launch of.the plan of prevention of.the Influenza Avian

'President Lula eats chicken after launching the Plan Against Avian Influenza.'

Experimentar

Experimentei a comida e muito estranha.

try.PST.1SG the food and COP.PST.3sg very strange

'I have tried the food and it was very strange.'

Perceber

Eu nunca percebi a comida com atenção.

1SG never perceive.PST.1SG the food with attention

'I have never perceived food with much attention.'

Provar

Provamos a feijoada vegetariana com arroz de coentros.

try.PST.1PL the feijoada vegetarian with rice of coriander

'We have tried vegetarian feijoada with coriander rice.'

\section{Saborear}

Equipe de socorristas da ONG Corpo Voluntário de Socorro e Resgate team the response of ONG team voluntary of search and rescue

RS unidade de Gravataítambém saboreou um cafezinho Melitta.

Rio Grande do Sul unit of Gravataíalso try.PST.3sg a

'The response team of the NGO Voluntary Search and Rescue Team from Rio Grande do Sul, Gravataí's unit, also tried a Melitta coffee.' 
Sentir

Quando dei a primeiragarfada senti

when took.PST.1SG the first bite taste.PST.1SG

a comida toda.

'When I took the first bite I tasted the whole dish.'

the meal whole

\section{Gustatory perception - State-of-Affairs}

Perceber

Percebo a cerveja descer amarga na garganta

taste.PRS.1SG a beer go.down.INF bitter in.the throat

'I taste the beer going down bitter in my throat.'

Sentir

$\begin{array}{lllllllll}\text { A } & \text { massa } & \text { é } & \text { bem macia, } & & & & \\ \text { the } & \text { dough } & \text { cop.PRS.3SG } & \text { very soft } & & & & \\ \text { mas } & \text { ao } & \text { morder você } & \text { sente } & \text { as } & \text { nozes } & \text { invadirem } & \text { sua } & \text { boca. } \\ \text { but } & \text { when } & \text { bite.INF 2SG } & \text { note.PRs.2SG } & \text { the } & \text { nuts } & \text { invade.INF.3PL } & \text { 2sG.Poss mouth }\end{array}$

'The dough is very soft, but when you bite it you notice the nuts invade your mouth.'

\section{Gustatory perception - Episode}

Perceber

Hoje, na hora do almoço,

today in.the hour of.the lunch

percebi que a comida estava sem gosto pra mim.

notice.PST.1SG that the food COP.PST.3SG without taste for 1SG.OBL

'Today, at lunch time, I noticed the food was tasteless for me.'

Sentir

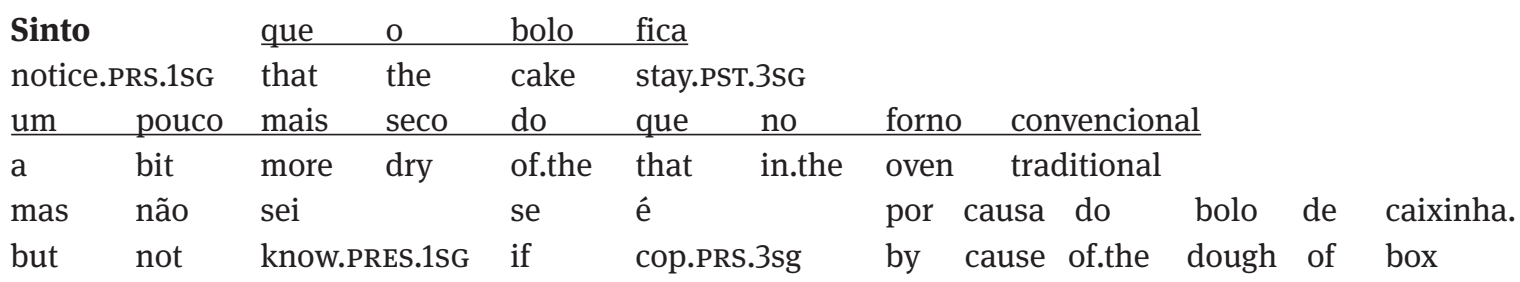

'I notice that the cake is a bit drier than when it is baked in the traditional oven, but I don't know if it is due to its prefabricated dough.' 


\section{Tactile perception - Property}

Apalpar

$\begin{array}{llllllll}\begin{array}{l}\text { Apalpei } \\ \text { touch.PST.1sG }\end{array} & \text { the } & \text { maciez larga } & \text { da } & \text { parte } & \text { carnuda } & \text { da } & \text { ave. }\end{array}$

'I touched the softness of the bird's fleshy part.'

Palpar

$\begin{array}{llllll}\text { Palpou } & \text { a maciez } & \text { do lençol buscando } & \text { através do } & \text { tato } \\ \text { touch.PST.3SG } & \text { the softness } & \text { of.the sheet try.PROG } & \text { through of.the } & \text { touch } \\ \text { tornar o } & \text { momento } \quad \text { mais } & \text { concreto } & & \\ \text { turn.INF the } & \text { moment } \quad \text { more } & \text { real } & \end{array}$

'He touched the sheet's softness trying to turn the moment more real by means of touch.'

\section{Perceber}

\section{Percebi}

notice.PST.1SG

a rigidez

dos

seus
músculos

quando Keaton apareceu para nos cumprimentar.

when Keaton came.PST.3SG to 1PL greet.INF

'I noticed the stiffness of his muscles when Keaton came to greet us.'

Sentir

Dei

take.PST.1SG

mais dois passos,

another two

steps

get_closer.1sG

e senti

and feel.PST.1SG

a maciez da pele sensual.

'I took another two steps, getting closer, and I felt the softness of his sensual skin.'

Tatear

Tateei

touch.PST.1SG

sabendo

maciez da pedra e

sorri

nervosa,

know.PROG

the

softness of.the

stone and

smile.PST.1SG

nervous

que

não

poderia

atirar na frente

dela.

'I touched the stone's softness and smiled nervously, because I knew I couldn't throw it at her.'

Tocar

Quando te vi toquei

a

aspereza touch.PST.1SG roughness the de tuas 2SG.POSS hands 


\section{Tactile perception - Individual}

Apalpar

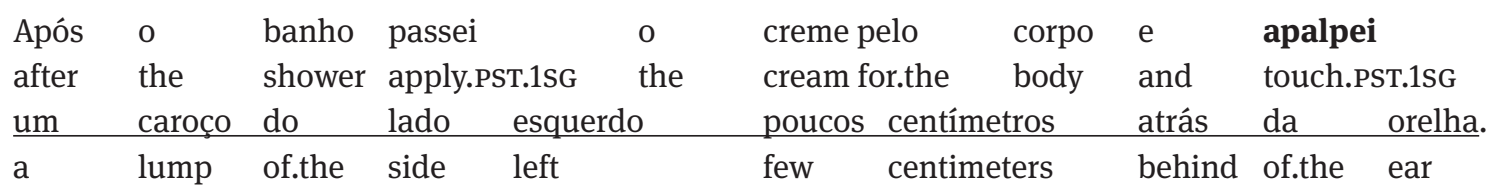

'After taking a shower, I applied the body cream and touched a lump on the left side a few centimeters behind my ear.'

Palpar

$\begin{array}{llllllllll}\text { Em } & \text { setembro, } & \text { depois } & \text { da } & \text { menstruação, } & \text { palpei } & \text { um } & \text { caroço, } \\ \text { in } & \text { September } & \text { after } & \text { of.the } & \text { period } & \text { touch.PST.1sG a } & \text { lump } & \\ \text { fiz } & \text { então } & \text { um } & \text { ultra } & \text { som } & \text { e } & \text { lá } & \text { estava } & \text { o } & \text { nódulo! } \\ \text { make.PST.1SG } & \text { then } & \text { an } & \text { ultra } & \text { sound and } & \text { there } & \text { cop.PST.3SG } & \text { the } & \text { lump }\end{array}$

'In September, after having my period, I touched a lump, an ultrasound was made and there it was, the lump.'

Perceber

$\begin{array}{llllllllll}\text { Assustado, } & \text { percebi } & \text { o } & \text { corpo } & \text { de } & \text { Guto } & \text { abraçado } & \text { ao } & \text { meu. } \\ \text { scare.PTCP } & \text { note.PST.1SG } & \text { the } & \text { body } & \text { of } & \text { Guto } & \text { hug.PTCP } & \text { at.the } & \text { 1SG.OBL }\end{array}$

'Freaked out, I noticed Guto's body hugging me.'

Sentir

\begin{tabular}{lllllllll} 
Sentiu & o & corpo & dela & em & seus & \multicolumn{2}{l}{ braços, } \\
feel.PST.3SG & the & body & of. 3sG & In & 3PL.Poss & arms & \\
quente como & o & sol & apesar do & frio de & Nova & Yorque. \\
hot like & the & sun & despite & of.the & cold of & New & York
\end{tabular}

'He felt her body in his arms, hot like the sun, although it was cold in New York.'

Tatear

$\begin{array}{llllll}\text { Quando } & \text { estava } & \text { quase morrendo } & \text { de } & \text { sede, } \\ \text { when } & \text { COP.PST.1SG } & \text { almost die.PROG } & \text { of } & \text { thirst } \\ \text { tateei } & \text { algo } & \text { parecido } & \text { com } & \text { uma } & \text { torneira. } \\ \text { touch.PST.1SG } & \text { something } & \text { similar } & \text { with } & \text { a } & \text { tap } \\ \text { 'When I was almost dying of thirst } & \text { Itouched something similar to a tap, }\end{array}$

'When I was almost dying of thirst, I touched something similar to a tap.' 
Tocar

$\begin{array}{lllll}\text { Também } & \text { toquei } & \text { seu } & \text { corpo } & \text { quente. } \\ \text { also } & \text { touch.PST.1SG } & \text { 3sG.POSS } & \text { body hot }\end{array}$

'I also touched his hot body which had liquor flavor.'

\section{Tactile perception - State-of-Affairs}

Perceber

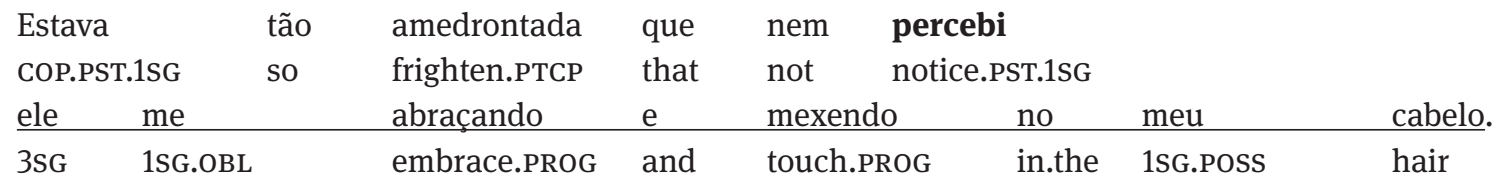

'I was so scared that I didn't notice he was embracing me and touching my hair.'

Sentir

$\begin{array}{lllll}\text { Senti } & \text { ela } & \text { mexer } & \text { de } & \text { verdade. } \\ \text { feel.PST.1SG } & \text { 3SG.F } & \text { move.INF } & \text { of } & \text { truth }\end{array}$

'I felt her move for real.'

\section{Tactile perception - Episode}

Perceber

Percebi

feel.PST.1SG

que Michele

me abraçou

apertado,

não tinha $j$ eito de escapar.

not have.PST.3SG way to scape

'I felt that Michele hugged me tightly, there was no way to escape.'

Sentir

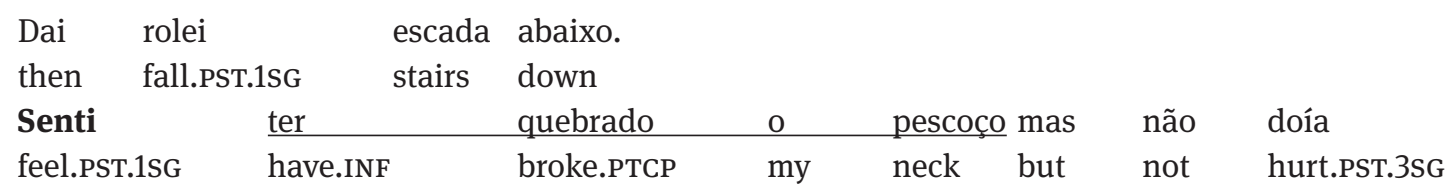

'Then I fell down the stairs and I felt I had broken my neck but it didn't hurt.' 


\section{Appendix 2: Morphosyntactic complement types with Brazilian Portuguese perception verbs}

\section{Escutar - e - progressive}

\begin{tabular}{|c|c|c|c|c|}
\hline Escutávamos & galera & gritando & "Ronaldinho" & direto. \\
\hline listen.PST.1PL & crowd & shout.PROG & "Ronaldinho" & constantly \\
\hline
\end{tabular}

Escutar - e - infinitive

$\begin{array}{llll}\mathrm{Eu} & \text { escutei } & \text { ela } & \text { cantar } \\ \text { 1SG } & \text { hear.PST.1SG } & \text { 3SG.F } & \text { sing.INF }\end{array}$

'I heard her sing.'

Escutar - ep - infinitive

Sinto m(u)(i)ta dificuldade de Warpar PsyTrance..

feel.PRS.1SG much difficulty of Warpar PsyTrance

Não fica perfeito...

not stay.PRS.3SG perfect

Escuto $\quad \underline{0} \quad$ kick não ter aquele impacto em alguns compassos.

hear.PRS.1SG the kick not have.INF that impact in some bars

'I have a lot of difficulty to work with Warpar PsyTrance (Record Company) ... it does not look perfect ... I hear the kick does not have that impact in some segments.'

Escutar - ep - finite

Tô

COP.PRS.1SG

escuto

hear.PRS.1SG

dançando na balada e

$$
\text { dance.PROG in.the party and }
$$

que a próxima música é uma que eu amo.

'I'm dancing at a party and I hear that the next song is one I love.'

Escutar - C - infinitive

Tem certas coisas horrorosas visualmente nos pés das mulheres, have.3.SG certain things horrible visibly in.the feet of.the women

que após meu questionamento,

which after 1SG.Poss questioning

escuto ser "extremamente confortável".

hear.PRS.1sG COP.INF "extremely comfortable"

'There are certain horrible things on women's feet, which upon my question, I hear to be "extremely comfortable."” 


\begin{tabular}{|c|c|c|c|c|c|c|c|c|c|c|}
\hline João & \multicolumn{2}{|c|}{ estava } & indo & para & \multirow{3}{*}{$\begin{array}{l}\text { casa } \\
\text { home } \\
\text { cidade }\end{array}$} & \multirow{3}{*}{$\begin{array}{l}\text { quando } \\
\text { when } \\
\text { da }\end{array}$} & \multirow{3}{*}{$\begin{array}{l}\text { ligou } \\
\text { turn.on.PST.3SG } \\
\text { India }\end{array}$} & \multirow{3}{*}{$\begin{array}{l}\text { o } \\
\text { the }\end{array}$} & \multirow{3}{*}{$\begin{array}{l}\text { rádio } \\
\text { radio }\end{array}$} & \multirow{3}{*}{$\begin{array}{l}\mathrm{e} \\
\text { and }\end{array}$} \\
\hline John & \multicolumn{2}{|c|}{ COP.PST.3SG } & \multicolumn{2}{|c|}{ go.PROG to } & & & & & & \\
\hline escuto & & que & em & uma & & & & & & \\
\hline hear.Ps & T.3SG & that & in & a & city & in & India & & & \\
\hline$\underline{\text { morrer }}$ & & três & pessoas & por & causa & de & gripe & desc & hecida. & \\
\hline die.PST & & three & people & by & cause & of & flu & unkr & wn & \\
\hline
\end{tabular}

Ouvir - e - progressive

\begin{tabular}{lllllllll} 
Eu & ouvi & & o & Diu & dizendo & que & o & serviço \\
1SG & hear.PST.1SG & the & Diu & say.PROG & that & the & service \\
vai & \multicolumn{2}{l}{ ser } & feito & lá & pelo & pessoal do & & Rio. \\
go.PRES.3SG & COP.INF & do.PTCP there & by.the people from.the & Rio
\end{tabular}

'I heard Diu saying that the service will be done by the people from Rio.'

Ouvir - e - infinitive

$\begin{array}{llllll}\text { Ouvi } & \text { cantar o } & \text { Ginguinhas } & \text { numa } & \text { taberna em } & \text { Samora. } \\ \text { hear.PST.1SG } & \text { sing.INF the } & \text { Ginguinhas } & \text { in.a } & \text { tavern in } & \text { Samora }\end{array}$

'I heard Ginguinhas sing in a tavern in Samora.'

Ouvir - ep - infinitive

Quando pego o telefone

when take.PRs.1sG the phone

ouço $\quad \underline{\text { modem não entrar na linha. }}$

hear.PRS.1SG the modem not enter.INF in.the line

'When I take the phone, I hear the modem doesn't connect.'

Ouvir - ep - finite

Quando pego o telephone

when take.PRS.1SG the phone

ouço que o modem não entra na linha.

hear.PRS.1SG that the modem not get.PRS.3sG on line

'When I take the phone I hear that the modem doesn't connect.'

Ouvir - C - infinitive

Outro ponto que ouvi another point that hear.PST.1SG Cop.INF a great point of view 'Another place I heard to be a great viewpoint.' 
Ouvir - C - finite

Durante a transmissão do jogo São Paulo vs Boca Juniors

during the broadcast of.the game São Paulo vs Boca Juniors

ouvi que o fla tá negociando

hear.PST.1SG that the Fla COP.PRS.3SG negotiate.PROG

$\begin{array}{llllllll}\text { com } & 0 & \text { Alex } & \text { Dias } & \text { para } & 0 & \text { ano } & \text { que } \\ \text { with } & \text { the } & \text { Alex } & \text { Dias } & \text { for } & \text { the } & \text { year that come.PRES.3.SG }\end{array}$

'During the transmission of the match São Paulo vs. Boca Juniors I heard that Fla(mengo) is negotiating with Alex Dias for next year.'

Ver - e - progressive

\begin{tabular}{|c|c|c|c|c|c|c|}
\hline $\mathrm{Eu}$ & $\mathrm{e}$ & $\mathrm{um}$ & amigo & vimos & & \\
\hline $\begin{array}{l}\text { 1SG } \\
\text { ele }\end{array}$ & $\begin{array}{l}\text { and } \\
\text { dando }\end{array}$ & $\mathrm{a}$ & $\begin{array}{l}\text { friend } \\
\text { um }\end{array}$ & $\begin{array}{l}\text { see.PST.1PL } \\
\text { empurrãozinho }\end{array}$ & no & antebraço. \\
\hline $3 \mathrm{SG}$ & give.PR & & $\mathrm{a}$ & push.DIM & in.the & forearm \\
\hline
\end{tabular}

'A friend and I saw him giving a small push on his forearm.'

Ver-e - infinitive

$\begin{array}{rlll}\text { Vi } & \text { um } & \text { carro } & \text { bater. } \\ \text { see.PST.1SG } & \text { a } & \text { car } & \text { crash.INF }\end{array}$

'I saw a car crash.'

Ver - ep - infinitive

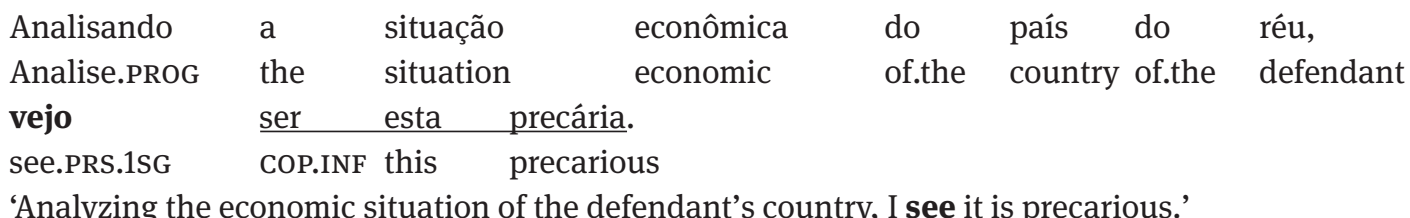

Ver - ep - finite

Eu vi que o carro tinha batido numa bike.

1SG see.PST.1SG that the car have.PST.3sg crash.PTcP in.a bicycle

'I saw that the car had crashed into a bicycle.'

Ver - C - infinitive

$\begin{array}{llllllll}\text { Hoje } & \text { mesmo } & \text { eu } & \text { vi } & \text { no } & \text { jornal } & & \\ \text { today } & \text { same } & \text { 1SG } & \text { see.PST.1SG } & \text { in.the } & \text { newspaper } & & \\ \text { Harry } & \text { Potter } & \text { já } & \text { bater a } & \text { maior } & \text { arrecadação } & \text { de } & \text { fim-de-semana } \\ \text { Harry } & \text { Potter } & \text { already } & \text { hit.INF the } & \text { highest box.office } & \text { of } & \text { weekend } \\ \text { com } & \text { U\$ } & 90 & \text { milhões nos } & \text { EUA, batendo Jurassic Park. } & \end{array}$


with U\$ 90 million in.the USA overtake.PRoG Jurassic Park

'Today I saw in the newspaper that Harry Potter has already hit the highest weekend box office with $\$ 90$ million in the USA, overtaking Jurassic Park.'

Ver-C - finite

$\begin{array}{llllllll}\text { Hoje } & \text { mesmo eu } & \text { vi } & \text { no } & \text { jornal } & \\ \text { today } & \text { same } & \text { 1SG } & \text { see.PST.1SG } & \text { in.the } & \text { newspaper } & \\ \text { que } & \text { Harry } & \text { Potter } & \text { já bateu a } & \text { maior arrecadação } & \text { de } & \text { fim-de-semana } \\ \text { that } & \text { Harry } & \text { Potter } & \text { already hit.PST.3SG } & \text { the highest box.office of } & \text { weekend } \\ \text { com } & \text { U\$ } & 90 & \text { milhões nos } & \text { EUA, } & \text { batendo } & \text { Jurassic Park. } & \\ \text { with } & \text { U\$ } & 90 & \text { million in.the USA } & \text { overtake.PRoG Jurassic Park } & \end{array}$

'Right today I saw in the newspaper that Harry Potter has already hit the highest weekend box office with $\$$ 90 million in the USA, overtaking Jurassic Park.'

\section{Avistar - e - progressive}

$\begin{array}{llllllll}\text { Avistei } & \text { ele } & \text { vindo } & \text { na } & \text { minha } & \text { direção } & \text { todo } & \text { lindo, } \\ \text { see.PST.1SG } & \text { 3SG } & \text { move.PROG } & \text { in.the } & \text { my } & \text { direction } & \text { all } & \text { handsome } \\ \text { vestindouma } & \text { camisa } & \text { branca, jaqueta } & \text { azul } & \text { e } & \text { calça jeans. } & & \\ \text { wear.PROG } & \text { a } & \text { shirt white } & \text { jacket } & \text { blue } & \text { and } & \text { trousers jeans } & \end{array}$

'I saw him moving toward me looking all handsome, in a white shirt, blue jacket and jeans.'

Avistar - e - infinitive

Avistamos $\quad$ Rich $\quad$ sair $\quad$ do $\quad$ carro.

see.PST.1PL Rich leave.INF of.the car

'We saw Rich leave the car.'

\section{Avistar - ep - infinitive}

Por fora já avistei ser um ambiente agradável.

by outside already see.PST.1SG be.INF a pleasant environment

'On the outside I already saw it was a pleasant environment.'

Avistar - ep - finite

Por um golpe de sorte,

by a stroke of luck

avistei que um dos carros

notice.PST.1SG that one of.the cars

estava deixando ostacionamento oficial" da instituição.

COP.PST.3SG leave.PROG the parking.lot official of.the institution

'By a lucky fluke, I noticed that one of the cars was leaving the institution's official parking lot .' 
Notar - e - progressive

$\begin{array}{lllllll}\text { Notou } & \text { uma } & \text { fã } & \text { cantando } & \text { músicas do } & \text { seu } & \text { álbum. } \\ \text { note.PST.3SG } & \text { a } & \text { fan } & \text { sing.PROG } & \text { songs from.the 3sG.Poss } & \text { album }\end{array}$

'He noticed a fan singing songs from his album.'

Notar - e - infinitive

Nem notaram $\underline{0}$ homem de paletó preto entrar apressado na sala.

Not note.PST.3PL the man in.a jacquet black enter.INF quickly in.the room

'They didn't notice the man in a black jacquet entering quickly into the room.'

Notar - ep - infinitive

\begin{tabular}{llllll} 
Notamos & ser & \multicolumn{3}{c}{ a espiritualidade } & \\
note.PST.1PL & COP.INF & & the spirituality & \\
algo & de & suma & importância & para & você. \\
something & of & great & importance & to & 2sG
\end{tabular}

'We noted that spirituality is something of great importance to you.'

Notar - ep - finite

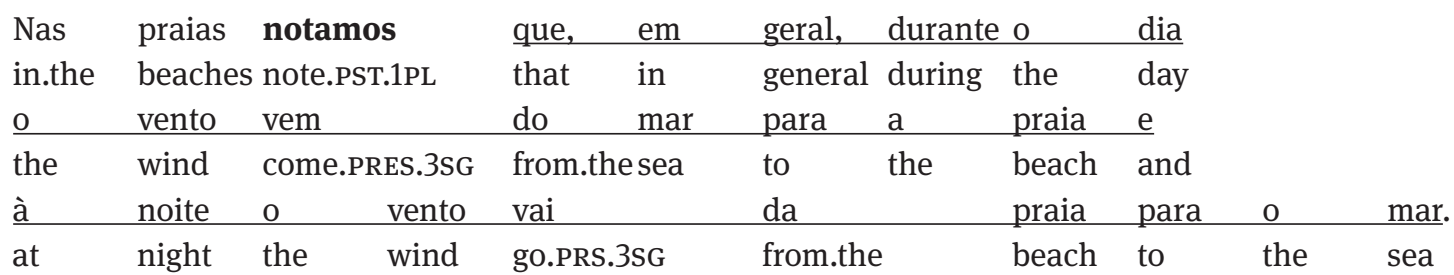

'On the beaches we note that, in general, during the day the wind comes from the sea to the beach and at night the wind goes from the beach to the sea.'

Observar - e - progressive

$\begin{array}{llllllll}\text { Eu } & \text { observei } & \text { eles } & \text { dormindo } & \text { por } & \text { mais } & \text { um } & \text { tempo } \\ \text { 1SG } & \text { watch.PST.1SG } & \text { 3PL } & \text { sleep.PROG } & \text { for } & \text { more } & \text { a } & \text { while } \\ \text { e } & \text { fui } & \text { pra } & \text { casa. } & & & & \\ \text { and } & \text { go.PST.1SG } & \text { to } & \text { house } & & & & \end{array}$

'I watched them sleeping for another while and went home.'

Observar - e - infinitive

Observamos a luz entrar no quarto.

observe.PST.1PL the light enter.INF in.the room

'We observed the light enter the room.' 


\begin{tabular}{|c|c|c|c|c|}
\hline Ele, & por & médico, & & \\
\hline $3 \mathrm{SG}$ & because COP.INF & doctor & & \\
\hline não & precisou & passar & pela & entrevista. \\
\hline not & need.PST.3SG & pass.INF & by.the & interview \\
\hline Sua & esposa & também & não, & \\
\hline 3SG.POS & wife & as.well & not & \\
\hline pois & observaram & uma & união & conflitos. \\
\hline for & observe.PST.3PL & COP.INF a & union & without conflict \\
\hline
\end{tabular}

'Because he is a doctor, he did not have to be interviewed. His wife did not either, for they observed it to be a union without conflict.'

Observar - ep - finite

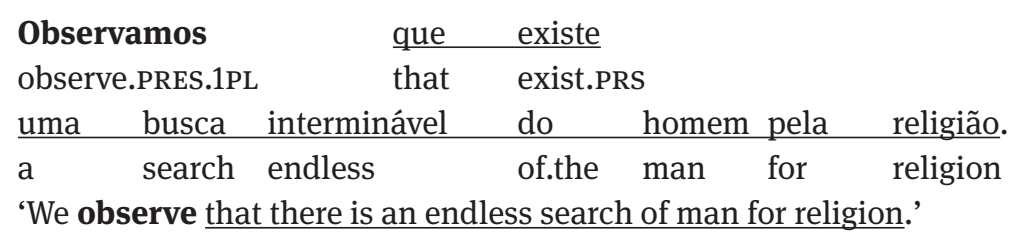

Perceber - e - progressive

$\begin{array}{lllllll}\text { Eu } & \text { percebi } & \text { eles } & \text { fazendo força } & \text { pra } & \text { arrancar } & \text { algo. } \\ \text { 1.SG } & \text { see.PST.1SG } & \text { 3.PL } & \text { do.PROG force } & \text { to } & \text { drag.INF } & \text { something }\end{array}$

'I saw them using force to drag something along.'

Perceber - e - infinitive

$\begin{array}{llllll}\text { Percebo } & \text { a } & \text { cerveja } & \text { descer } & \text { amarga na } & \text { garganta } \\ \text { taste.PRS.1SG } & \text { the } & \text { beer } & \text { go.down.INF } & \text { bitter in.the throat }\end{array}$

'I taste the beer going down bitter in my throat.'

Perceber - ep - infinitive

Percebemos ser essencial

feel.PST.1PL COP.INF essential

$\begin{array}{llllllll}\text { o } & \text { conhecimento } & \text { de } & \text { como } & \text { tais } & \text { teorias } & \text { se } & \text { constroem } \\ \text { the } & \text { knowledge } & \text { of } & \text { how } & \text { such } & \text { theories } & 3 . R E F L & \text { construct.3PL }\end{array}$

'We feel the knowledge of how these theories are constructed to be essential.'

Perceber - ep - finite

Percebo que o mundo está cansado de sonhadores!

realize.PRS.1SG that the world COP.PRS.3SG tired of dreamers

'I realize that the world is tired of dreamers!' 
Sentir - e - progressive

$\begin{array}{lllllll}\text { Senti } & \text { algo } & \text { entrando } & \text { dentro } & \text { do } & \text { meu } & \text { corpo. } \\ \text { feel.PST.1SG } & \text { something } & \text { enter.PROG } & \text { inside } & \text { of.the } & \text { 1sG.POSS } & \text { body } \\ \text { 'I felt something entering my body.' } & \end{array}$

Sentir - e - infinitive

$\begin{array}{llllllll}\text { A } & \text { massa } & \text { é } & \text { bem macia, } & & & \\ \text { the } & \text { dough } & \text { cop.PRs.3sg } & \text { very soft } & & & & \\ \text { mas } & \text { ao } & \text { morder você } & \text { sente } & \text { as } & \text { nozes invadirem } & \text { sua } \\ \text { but } & \text { when } & \text { bite.PRog 2sG } & \text { note.PRS.2sG } & \text { the } & \text { nuts } & \text { invade.INF.3PL } & \text { 2sG.Poss mouth }\end{array}$

'The dough is very soft, but when you bite it you notice the nuts invade your mouth.'

Sentir - ep - infinitive

Dai rolei escada abaixo.

then fall.PST.1sG stairs down

Senti ter quebrado o pescoço mas não doía.

feel.PST.1SG have.INFbroke.PTCP the neck but not hurt.PST.3SG

'Then I fell down the stairs and I felt I had broken my neck but it didn’t hurt.'

Sentir - ep - finite

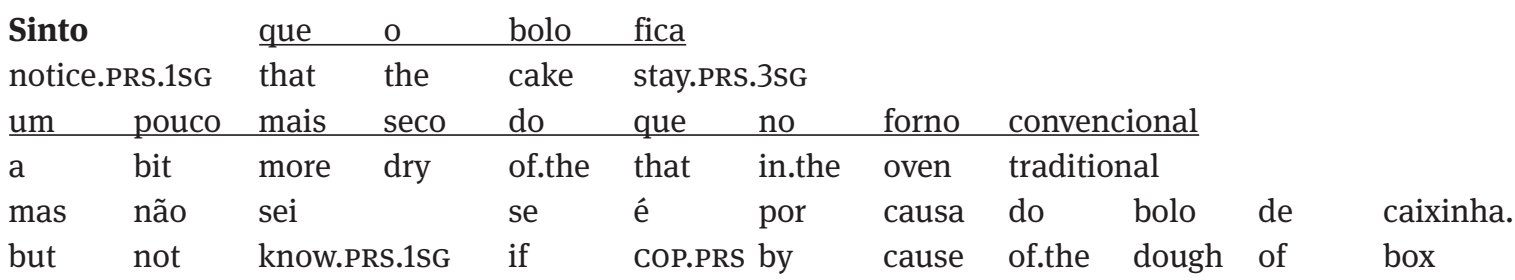

'I notice that the cake is a bit drier than when it is baked in the traditional oven, but I don't know if it is due to its prefabricated dough.'

Visualizar - e - progressive

Uma vez visualizei Deus pairando sobre a

one time visualize.PST.1sG God hover.PROG over the Earth

'Once I visualized God hovering over the Earth.'

Visualizar - e - infinitive

Ao se aproximar do veículo em questão,

at.the REFL approach.INF of.the vehicle in question

visualizou ser jogada pela janela uma sacola.

see.PST.3SG COP.INF throw.out.PST.PRTC by.the window a bag

'As he approached the vehicle in question, he saw a bag being thrown out of the window.' 
Visualizar - ep - infinitive

O presidente da Funai, Mércio Pereira Gomes,

the presidente of.the Funai Mércio Pereira Gomes

visualizou ser possível

fazer valer

visualize.PST.3SG COP.INF possible

do.INF assert.INF

os direitos das etnias indígenas

the rights of.the ethnic.groups indigenous

para 0 acesso ao ensino diferenciado.

for the access to.the instruction differentiated

'The president of Funai, Mércio Pereira Gomes, visualized that it is possible to assert the rights of indigenous ethnic groups to access differentiated instruction.

Visualizar - ep - finite

A $\begin{aligned} & \text { autora } \\ & \text { the visualizou }\end{aligned}$ author visualize.PST.3SG $\quad \begin{aligned} & \text { que } \\ & \text { that }\end{aligned}$ the
sempre estiveram women of

